University of South Carolina

Scholar Commons

$6-2010$

\title{
Structural and Stratigraphic Control on the Migration of a Contaminant Plume at the P Reactor Area, Savannah River Site, South Carolina
}

\author{
Antonio E. Cameron González \\ University of South Carolina - Columbia \\ Camelia C. Knapp \\ University of South Carolina - Columbia, camelia@geol.sc.edu \\ Michael G. Waddell \\ University of South Carolina - Columbia \\ Adrian Addison \\ University of South Carolina - Columbia \\ John M. Shafer \\ University of South Carolina - Columbia \\ Follow this and additional works at: https://scholarcommons.sc.edu/geol_facpub \\ Part of the Earth Sciences Commons
}

\section{Publication Info \\ Published in Environmental Geosciences, ed. American Association of Petroleum Geologists, Volume 17, Issue 2, 2010, pages 77-98. \\ Cameron González, A. E., Knapp, C. C., Waddell, M. G., Addison, A. D., \& Shafer, J. M. (2010). Structural and stratigraphic control on the migration of a contaminant plume at the $\mathrm{P}$ Reactor area, Savannah River site, South Carolina. Environmental Geosciences, 17 (2), 77-98. \\ (c) Environmental Geosciences 2010, The American Association of Petroleum Geologists/Division of Environmental Geosciences}

This Article is brought to you by the Earth, Ocean and Environment, School of the at Scholar Commons. It has been accepted for inclusion in Faculty Publications by an authorized administrator of Scholar Commons. For more information, please contact digres@mailbox.sc.edu. 


\section{Structural and stratigraphic} control on the migration of a contaminant plume at the $P$ Reactor area, Savannah River site, South Carolina

\author{
Antonio E. Cameron González, Camelia C. Knapp, \\ Michael G. Waddell, Adrian D. Addison, and \\ John M. Shafer
}

\begin{abstract}
Geophysical methods, including a shallow seismic reflection (SSR) survey, surface and borehole ground-penetrating radar (GPR) data, and electrical resistivity imaging (ERI), were conducted at the Savannah River site (SRS), South Carolina, to investigate the shallow stratigraphy, hydrogeophysical zonation, and the applicability and performance of these geophysical techniques for hydrogeological characterization in contaminant areas. The study site is the P Reactor area located within the upper Atlantic coastal plain, with clastic sediments ranging from Late Cretaceous to Miocene in age. The target of this research was the delineation and prediction of migration pathways of a trichloroethylene (TCE) contaminant plume that originates from the northwest section of the reactor facility and discharges into the nearby Steel Creek. This contaminant plume has been migrating in an east-to-west direction and narrowing away from the source in an area where the general stratigraphy along with the groundwater flow dips to the southeast. Here, we present the results from a stratigraphic and hydrogeophysical characterization of the site using the SSR, GPR, and ERI methods. Although detailed stratigraphic layers were identified in the upper approximately $50 \mathrm{~m}$ (164 ft), other major findings include (1) the discovery of a shallow ( $\sim 23 \mathrm{~m}[75 \mathrm{ft}]$ from the ground surface) inverse fault, (2) the detection of a paleochannel system that was previously reported but that seems to be controlled by the reactivation of the interpreted fault, and (3) the finding that the hydraulic gradient seems to have a convergence of groundwater flow near the area. The interpreted fault at the study site appears to be of upper Eocene age and may be associated with other known reactivated faults within the Dunbarton
\end{abstract}

Copyright (C2010. The American Association of Petroleum Ceologists/Division of Environmental Geosciences. All rights reserved.

DOI:10.1306/eg.08180909012

\section{AUTHORS}

Antonio E. CAmeron González Department of Earth and Ocean Sciences, University of South Carolina, 701 Sumter St., EWS 617, Columbia, South Carolina 29208; acameron@geol.sc.edu

Antonio Cameron is a Ph.D. candidate in the Department of Earth and Ocean Sciences at the University of South Carolina. He received M.S. and B.S. degrees in geology from the University of Puerto Rico at Mayagüez and worked for 3 years as a researcher in the Puerto Rico Seismic Network. His research interests include exploration and environmental geophysics, earthquake seismology, and geostatistics.

CAMELIA C. KnAPP $\sim$ Department of Earth and Ocean Sciences, University of South Carolina, 701 Sumter St., EWS 617, Columbia, South Carolina 29208

Camelia Knapp received a Ph.D. in geophysics from Cornell University and B.S. and M.S. degrees in geophysical engineering from the University of Bucharest (Romania). She worked with the Romanian State Oil Company and the National Institute for Earth Physics. Currently at the University of South Carolina in the Department of Earth and Ocean Sciences, her research interests include exploration and environmental geophysics, crustal-scale seismology, and gas hydrates.

MiCHAEL G. WADDELL Earth Sciences and Resources Institute, University of South Carolina, 1233 Washington St., Suite 300, Columbia, South Carolina 29208

Michael Waddell completed his graduate studies at Earth Sciences and Resources InstituteUniversity of South Carolina (ESRI-USC), in 1982 and remained at ESRI-USC until 1984 when he became a reservoir geologist in Houston working on petrographic investigations of hydrocarbon reservoirs worldwide. In 1986, he returned to ESRI-USC to start an environmental geophysics group and is presently its manager.

ADRIAN D. AdDISON $\sim$ Earth Sciences and Resources Institute, University of South Carolina, 1233 Washington St., Suite 300, Columbia, South Carolina 29208

Adrian Addison received his Ph.D. in geological sciences from the University of South Carolina. 
He received a B.S. degree in geophysics from the University of Oklahoma and worked for 4 years as a geophysicist with the U.S. Geological Survey. He recently joined ESRI-USC as a researcher associate, and his research interests include borehole and near-surface geophysics, environmental geology, and signal processing.

JOHN M. SHAFER $\sim$ Earth Sciences and Resources Institute, University of South Carolina, 1233 Washington St., Suite 300, Columbia, South Carolina 29208

John Shafer received his Ph.D. in civil engineering from Colorado State University, his M.S. degree in resource development from Michigan State University, and his B.S. degree in earth science from Penn State University. His research focus includes integrated site characterization, coupled simulation-optimization approaches to solving groundwater problems, and groundwater susceptibility and contamination potential analysis.

\section{ACKNOWLEDGEMENTS}

We thank Duke Brantley from the Earth Sciences and Resources Institute; Susan Hubbard, John Peterson, Michael Kowalsky, and Kenneth Williams from Lawrence Berkeley National Laboratory; and Gregg Flach, Marry Harris, and Margaret Milling from Savannah River National Laboratory. Special thanks go to James Knapp and Jose Manuel Bacale as well as to the Geophysical Exploration and the Tectonics Geophysical Laboratories from the Department of Earth and Ocean Sciences at the University of South Carolina. We also acknowledge Landmark Graphics Corporation, Seismic MicroTechnology Inc., and Environmental Systems Research Institute (ProMax ${ }^{\circledR}$, Kingdom ${ }^{\circledR}$ Suite and ArcGISTM software packages) for the University Grants Programs. This work was made possible through a grant by the Office of ScienceBiological and Environmental Research of the U.S. Department of Energy (grant DE-FG0206ER64210).
Triassic Basin. The coincident use of the SSR and ERI methods in conjunction with the complementary 50-, 100-, and 200-MHz GPR antennas allowed us to generate a detailed geologic model of the shallow subsurface, suggesting that the migration of the TCE plume is constrained by (1) the paleochannel system with respect to its migration direction, (2) the presence of an inverse fault that may also contribute to the paleochannel growth and structural evolution, and (3) the local groundwater flow volume with respect to its longer and narrower shape away from the source updip stratigraphic bedding.

\section{INTRODUCTION}

An integrated surface and borehole geophysical investigation, including a shallow seismic reflection (SSR), surface and borehole ground-penetrating radar (GPR), and electrical resistivity imaging (ERI) surveys, were conducted at the P Reactor area, Savannah River site (SRS), South Carolina, to assess the local shallow stratigraphy and structural geology and to test the viability of the combined methods in an area with interspersed sand and clay layers and where the general stratigraphic dip along with the regional groundwater flow is to the southeast (Figure 1). Precharacterization efforts within the study area revealed that the groundwater is primarily contaminated with volatile organic compounds and tritium (Millings et al., 2003). Several contaminant plumes have been identified, and the plume of interest contains trichloroethylene (TCE) that originates from the northwest section of the reactor facility and discharges into the nearby Steel Creek. Moreover, despite the stratigraphic layers having a slight northwest-southeast dip in the study area (Snipes et al., 1993), the contaminant plume seems to flow updip and narrows away to the west from the source area instead of showing an expected broadening pattern and flow migration to the southeast (Figure 2). The P Reactor area at SRS, which is a Department of Energy facility encompassing about $300 \mathrm{mi}^{2}\left(777 \mathrm{~km}^{2}\right)$ of land, lies within the upper Atlantic coastal plain (UACP), a southeast-dipping wedge of unconsolidated and semiconsolidated sediments that extend from its contact with the Piedmont Province at the Fall Line to the edge of the continental shelf (Figure 1). The sedimentary cover $(<100 \mathrm{~m}[328 \mathrm{ft}])$ ranges from the Paleocene to Miocene in age and comprises layers of sand, muddy sand, and mud with minor amounts of calcareous sediments (Siple, 1967; Marine, 1974; Fallaw et al., 1990; Colquhoun and Muthig, 1991; Nystrom et al., 1991; Sohl and Owens, 1991; Fallaw and Price, 1992, 1995) (Figure 3).

Combined geophysical methods such as SSR, GPR, and ERI have been used in the identification of shallow sediments $(<100 \mathrm{~m}$ [328 ft]) in different applications such as environmental, hydrological, geotechnical, and engineering studies (Wyatt et al., 1996). Indeed, detection of shallow porous layers, characterization of sediments and shallow layering, recognition of bed rocks, examination 


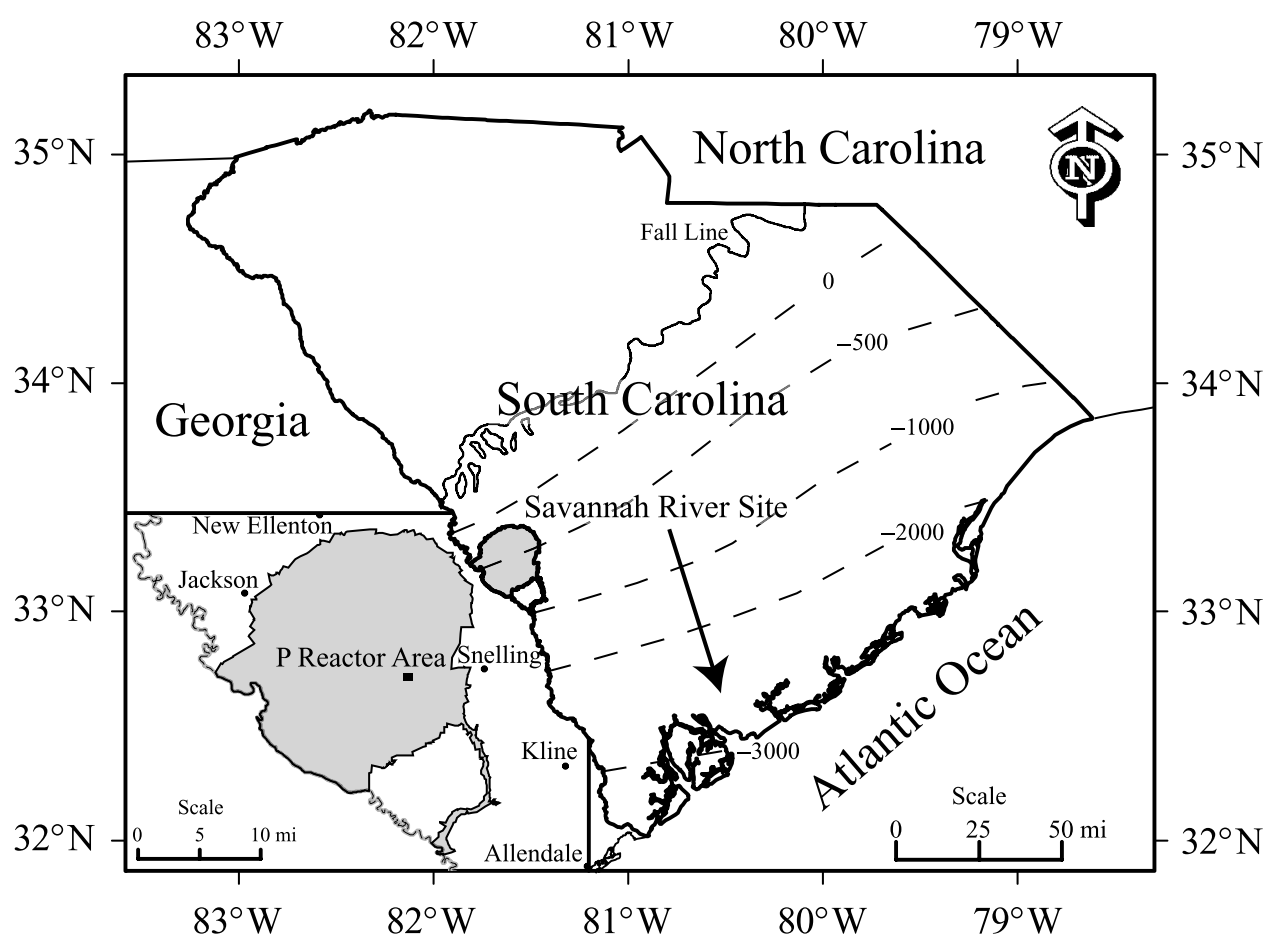

Figure 1. Location map of the P Reactor area at Savannah River site (SRS), west-central South Carolina. The approximate altitude of the basement rock surface in the Atlantic coastal plain is also shown (dashed lines) (from Cederstrom et al., 1979). Contour interval is in feet. The general stratigraphic dip of coastal plain sediments and regional groundwater flow (black arrow) is to the southeast (Aucott, 1996). of aquifers, and/or location of buried objects and structural features such as faults are some examples of primary interest in shallow subsurface applications, especially in areas with near-surface contamination. In many geological environments, SSR, GPR, and ERI are effective methods for imaging near-surface boundaries due to variations in stratigraphy and in electromagnetic (EM) properties, obtaining detailed, horizontally continuous information about the near subsurface without resorting to invasive and expensive drilling (Neal, 2004). Geologic complexity such as cross-stratification, conflicting dips, joints and faults, or rapid lateral and vertical particle-size variations pose a challenge in the interpretation of the shallow stratigraphy using SSR, GPR, and ERI methods (Wyatt and Temples, 1996; Baker et al., 2001; Gross et al., 2004; Clement et al., 2006). However, the use of a combination of these methods generally improves the chances for a more accurate geologic interpretation.

Seismic reflections arise from changes in seismicwave velocity and mass density. In contrast, GPR reflections (or near-surface EM boundaries) may be generated by changes in the dielectric permittivity, magnetic permeability, and/or electrical conductivity caused by variable moisture content within a clastic unit, or simply by lithologic variations. Regularly, GPR methods are used

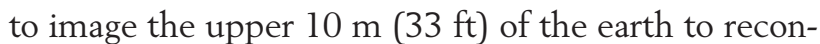
struct past depositional environments and the nature of sedimentary processes in a variety of geologic settings except where electrical conductivity is uncommonly low, which allows the radar signal to penetrate more deeply. Thus, EM parameters (i.e., dielectric permittivity, magnetic permeability, and electrical conductivity) may change across an interface when bulk density, seismicwave velocity, and/or resistance to current flow remain constant. However, EM parameters may remain unchanged across an interface when these other physical properties vary. As a result, resistance anomalies would appear in the ERI but not in the GPR data.

In ERI methods, direct current or low-frequency alternating current is applied to the ground surface, and the potential difference is measured between two points. Variations in resistance to current flow at depth cause distinctive variations in the potential difference measurements, which provide information about the subsurface structures and materials. Although these techniques work well in near-surface investigations and are quite similar in terms of how the active energy is applied to the earth, GPR still offers the highest potential resolution of the three methods for shallow imaging in low EM loss materials (Baker et al., 2001).

In site characterization, near-surface geophysical surveys at different resolution scales are critical to model the heterogeneity of the shallow subsurface. These noninvasive geophysical methods respond to changes in the material composition and pore fluid 
Figure 2. Lateral extension of the trichloroethylene (TCE) plume that originates from the northwest section of the P Reactor facility and discharges into the nearby Steel Creek (west of the study area). The brown dashed line is an outline of the geophysical survey area. The plume map shows concentration ranging from 5 to $10,000 \mu \mathrm{g} / \mathrm{L}$ and were determined from cone penetrometer tests (CPTs) and well data (blue triangles and green dots). Note that the highest TCE concentrations are not very well constrained because of the sparse coverage of the CPT wells. Core and natural gamma logs (POS wells; POS stands for position) as well as four piezometers (magenta dots) for potentiometric surface data used in this investigation are also shown.

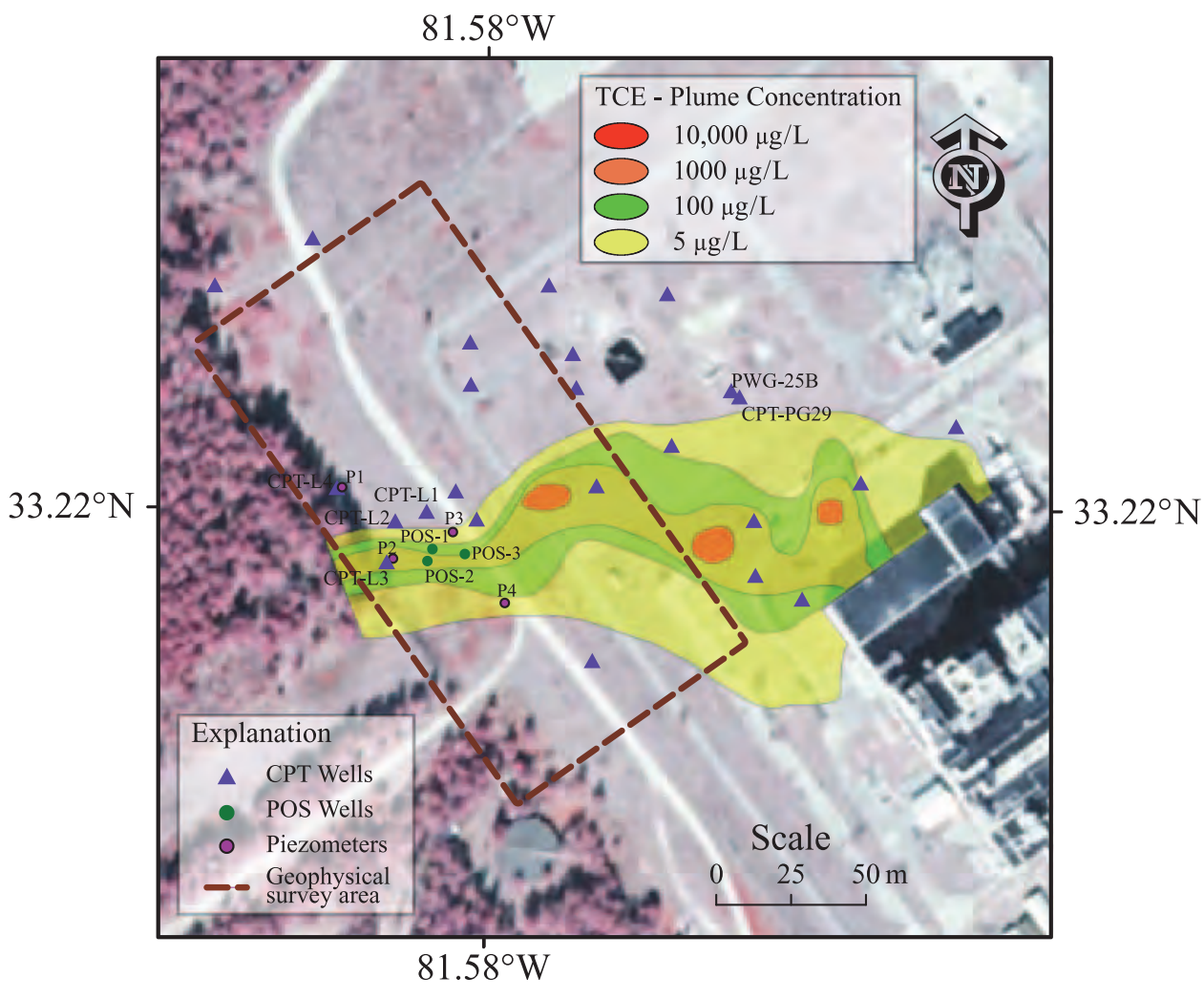

of the subsurface, therefore, corresponding and complementary imaging of the subsurface can be achieved by these three methods. Moreover, they have the potential to provide more cost-effective and reliable information for performance monitoring of contaminated site characterization.
Figure 3. Shallow stratigraphic units, including lithostratigraphy (modified from Fallaw and Price, 1995), sequence stratigraphy, and hydrostratigraphy (modified from Aadland et al., 1995) for the SRS region.

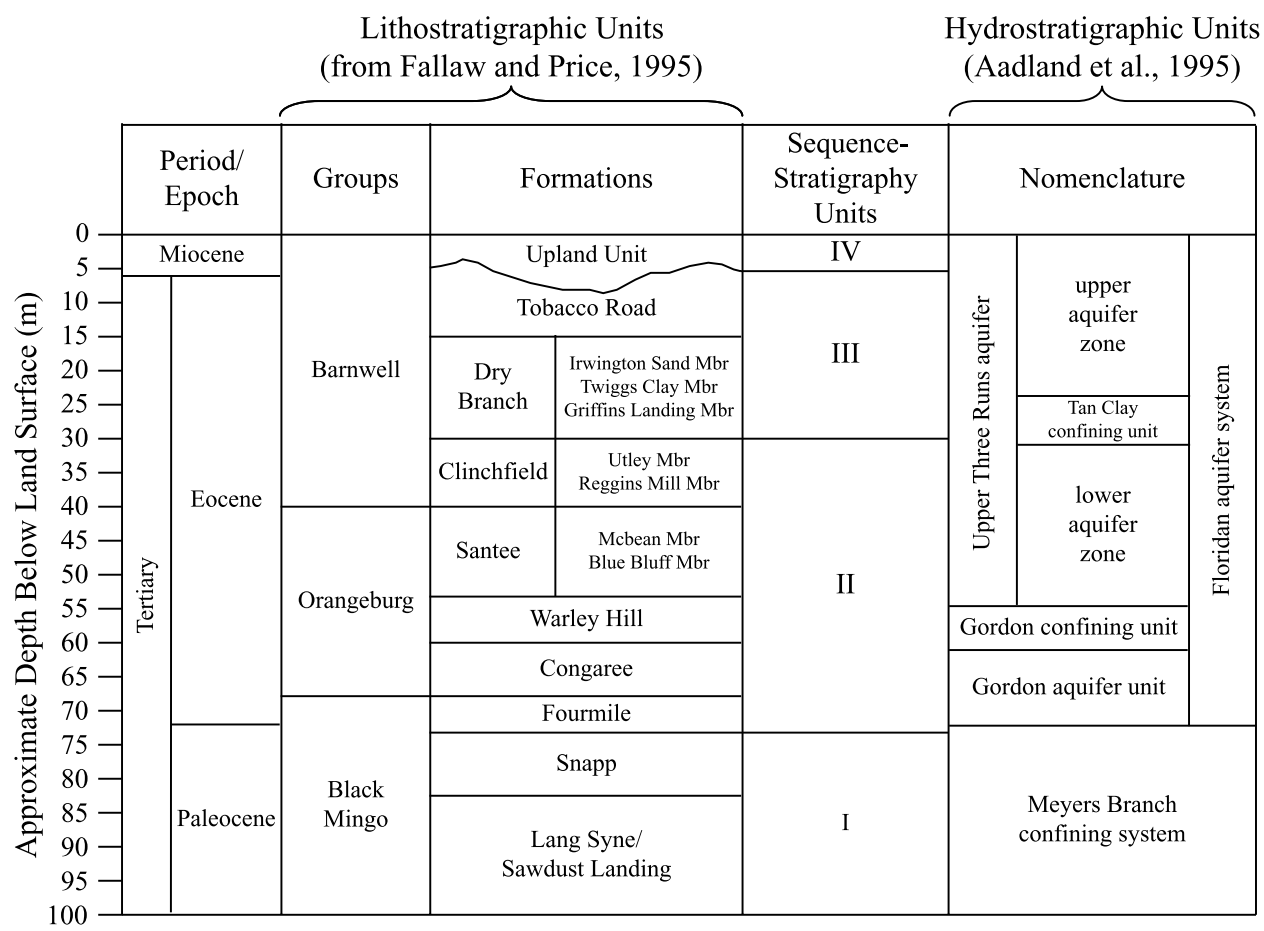




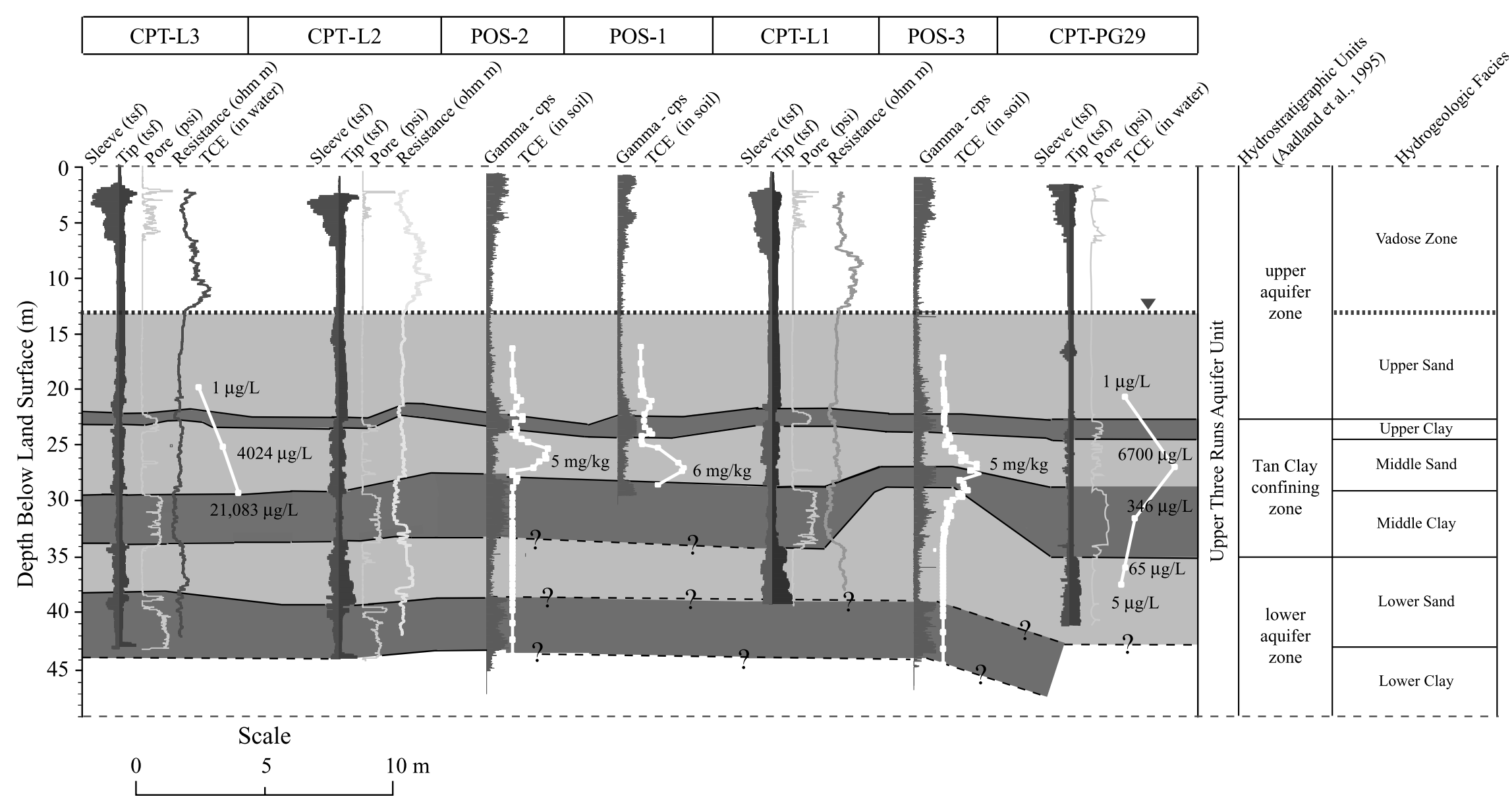

Figure 4. Cone penetrometer tests (CPT) and natural gamma log correlation with hydrostratigraphic units and hydrogeologic facies for our study area (modified from Addison et al., 2009). The water table is approximately at 13-m (43-ft) depth dividing the upper Three Runs aquifer into seven hydrogeologic facies. Wyatt et al. (2000) indicated that the upper aquifer zone consists of massive beds of sand and clayey sand with minor interbeds of clay, the Tan Clay confining zone contains light-yellowish tan to orange clay and sandy clay interbeded with clayey sand and sand, and the lower aquifer zone is composed of siliciclastic and calcareous sediments of the Santee Formation and parts of the Dry Branch Formation. tsf = tons per square foot; TCE = trichloroethylene. 


\section{STUDY AREA AND HYDROGEOLOGIC SETTING}

The shallow ( $\sim 75 \mathrm{~m}[246 \mathrm{ft}])$ hydrogeologic units at SRS involve Tertiary-age sediments, mainly Eocene to Miocene in age (Figure 3). The updip part of the Floridan aquifer system includes the Gordon aquifer, the Gordon confining unit, and the upper Three Runs aquifer (UTRA) (Aadland et al., 1995). The UTRA includes the Upland unit, Tobacco Road Sand, Dry Branch Formation, Clinchfield Formation, and Santee Limestone. At the P Reactor area, the UTRA is informally divided in lower and upper aquifer zones (LAZ and UAZ) separated by the Tan Clay confining zone (TCCZ). For the purpose of this article, the UTRA has been divided among seven major hydrogeologic facies, which address specific characteristics for the UAZ, the TCCZ, and the LAZ (Figure 4).

The regional groundwater flow system in the Atlantic coastal plain of South Carolina is considered to be a stratified system (Aucott, 1996), where water enters the system as recharge in topographically high areas between rivers and lakes, flows southeast down the hydraulic gradient, and discharges to other rivers, lakes, swamps, and/or to the Atlantic Ocean. However, in a local spatial scale, based on potentiometric surface data from depth-discrete piezometers, the shallow groundwater in the study site appears to have a predominantly west to southwest flow direction.

Several studies of coastal plain geology at, and in the vicinity of, SRS (e.g., Higgins et al., 1978; Zoback et al., 1978; Behrendt et al., 1983; Hamilton et al., 1983; Schilt et al., 1983; Talwani, 1986; Shedlock and Harding, 1988; Snipes et al., 1993; Wyatt and Temples, 1996; Wyatt et al., 1996) have documented faults in the coastal plain sediments that appear to be closely related to the Mesozoic extensional basement structure. To recognize the coastal plain sediments as a layer-cake model is an oversimplification of an area where faulting is present in several localities. Based on seismic data from Behrendt et al. (1983) and Chapman and Di Stefano (1989), Cenozoic movements were documented above several Triassic basins in South Carolina that caused reactivation of Triassic normal faults as inverse faults.

\section{DATA ACQUISITION AND PROCESSING}

This study included (1) geophysical data collection and interpretation, (2) hydrogeophysical characterization of the study area, and (3) integration and analysis of site characterization results as they relate to the study of the TCE contaminant plume. The SSR survey was performed with a Geometrics 120-channel StrataView ${ }^{\circledR}$ seismograph, the surface and crosshole GPR data were acquired with the PulseEKKO 100 system by Sensors \& Software, Inc. with 50-, 100-, and 200-MHz antennas, and the ERI was conducted with the SuperSting R8 IP with an 8-channel multielectrode resistivity system (Figure 5). Three cone penetrometer tests (CPTs) and three natural gamma logs with the associated core descriptions for three wells (POS-1, -2, and -3; POS stands for position) were provided by the Savannah River National Laboratory (SRNL) (Figure 4). These techniques and the subsequent results are described below.

\section{Cone Penetrometer Tests and Natural Gamma Logs}

The CPT is a subsurface soil exploration method that involves pushing a conical-shaped probe into a soil deposit and records sleeve frictions and tip resistance along with electrical resistivity, natural gamma, spontaneous potential, velocity data, piezometric values, and a variety of other geophysical parameters (Lunne et al., 1997). Natural gamma-ray measurements were used to characterize the rock or sediments in three boreholes (POS wells) by detecting variations in the natural radioactivity originating from changes in concentrations of the trace elements uranium (U) and thorium (Th) as well as changes in concentration of the major rock-forming element potassium (K). Because the concentrations of these naturally occurring radioactive elements vary between different rock types, natural gamma-ray logging provides an important tool for lithologic mapping and stratigraphic correlation. Natural gamma logs are sometimes used in mineral exploration and water-well drilling but most commonly for formation evaluation in oil- and gas-well drilling (Paillet and Ellefsen, 2005). The locations of the CPT and natural gamma logs (POS wells) are shown in Figure 2.

\section{Shallow Seismic Reflection Data}

A pilot two-dimensional (2-D) SSR survey was conducted at the study site during the summer of 2007 to provide larger depth control for the regional stratigraphic and structural geologic characterization and to serve as a calibration tool for a future three-dimensional 


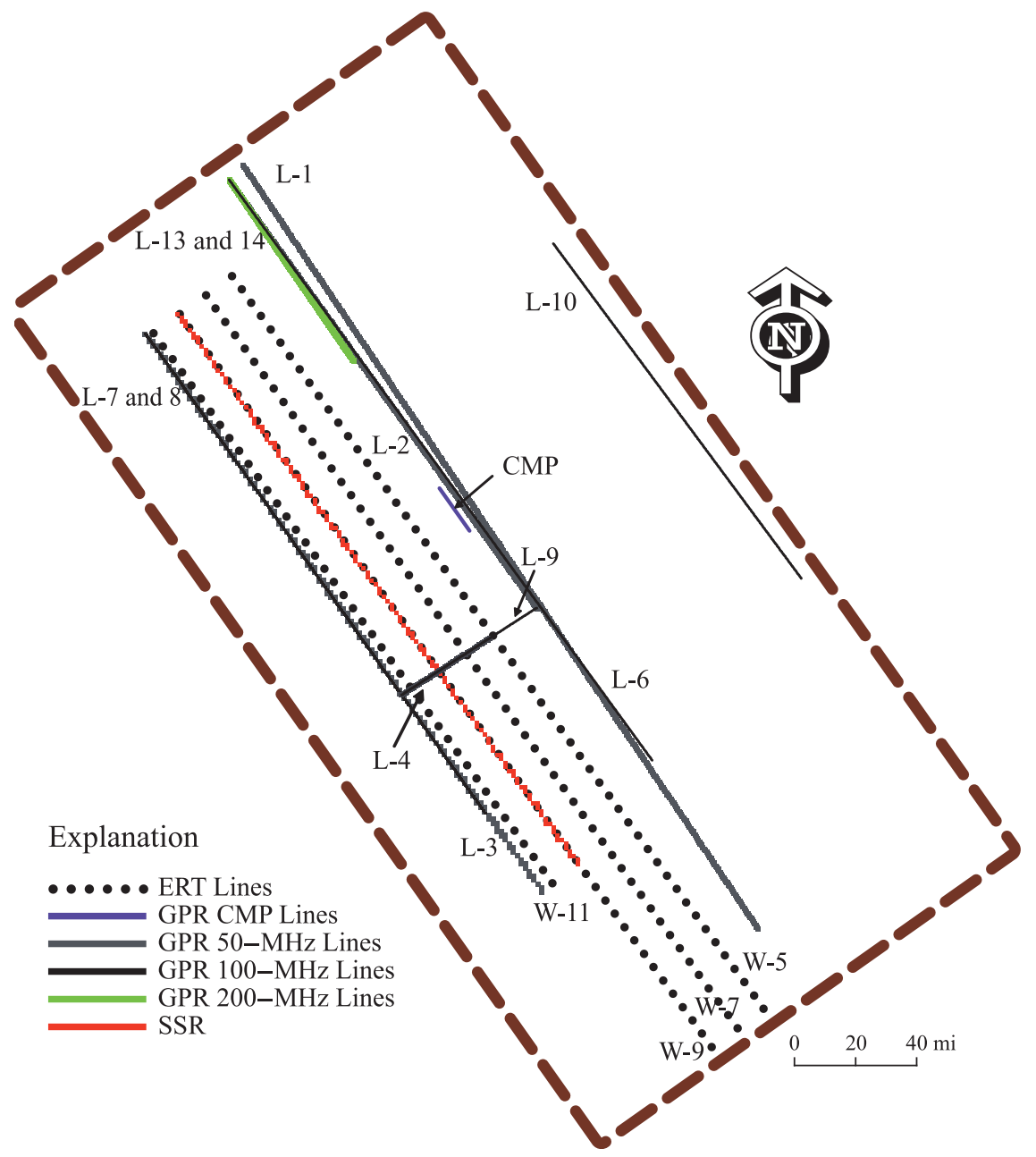

Figure 5. Layout of the shallow seismic reflection (SSR), ground-penetrating radar (GPR), and electrical resistivity imaging (ERI) lines.

(3-D) seismic reflection survey (Addison et al., 2009) (Figure 5). To improve the quality of the SSR data, several critical acquisition factors have been considered, including a fast sample rate $(0.5 \mathrm{~ms})$ and close spatial sampling ( $1 \mathrm{~m}[3 \mathrm{ft}])$ to improve the vertical and horizontal resolutions. The specific acquisition parameters for the SSR survey are shown in Table 1. The seismic data were processed with the Landmark Graphics' ProMax ${ }^{\circledR}$ software using the following sequence: (1) geometry assignment, (2) trace edits, (3) elevation statics, (4) top mute, (5) spherical divergence correction, (6) F-K filter, (7) bandpass filter, (8) deconvolution, (9) velocity analysis, (10) amplitude scaling, (11) normal move out and sectioning, (12) migration, and (13) time to depth conversion. Table 2 lists the processing sequence used in generating the final 2-D seismic section shown in Figure 6. The SSR line was imported for further interpretation along with the natural gamma and electrical resistivity logs from the POS and CPT wells into Kingdom ${ }^{\circledR}$ Suite.

\section{Surface Ground-Penetrating Radar}

Nine common offset GPR transects were acquired at the study site (Figure 5). In addition, two common-midpoint (CMP) gathers were used to identify reflection events

Table 1. Acquisition Parameters for the Shallow Seismic Reflection (SSR) Data Collected at the P Reactor Area, Savannah River Site, South Carolina

\begin{tabular}{ll}
\hline Acquisition Parameter & \multicolumn{1}{c}{ Value } \\
\hline Geophone spacing & $1 \mathrm{~m}$ \\
Sample rate & $0.5 \mathrm{~ms}$ \\
Record length & $500 \mathrm{~ms}$ \\
10-ft sledge hammer & 4 to 6 stacks \\
Total shots & 170 \\
Fold & 30 \\
Geophone frequency & $40 \mathrm{~Hz}$ \\
\hline
\end{tabular}


Table 2. Generalized Processing Sequence in Generating the Final Seismic Section

\begin{tabular}{ll}
\hline Processing & \\
\hline Geometry & Straight line geometry \\
Trace edits & Eliminated noisy traces \\
Elevation statics & Elevation corrections of stations \\
Top mute & Eliminated refraction arrivals \\
Spherical divergence correction & Applied $1 /$ (time $\times$ [velocity $]^{2}$ function with a 0.0002 inelastic attenuation correction, \\
& a velocity function of $300 \mathrm{~m} / \mathrm{s}$ for 100 ms and $1500 \mathrm{~m} / \mathrm{s}$ between $100 \mathrm{ms,}$ with a \\
F-K filter & time-power constant of 1.4 \\
Bandpass filter & Arbitrary polygon to reject ground-roll noise \\
Deconvolution & Single filter Ormsby bandpass with corner frequencies of $50-100-300-400 \mathrm{~Hz}$ \\
& Spiking/predictive deconvolution using minimum-phase spiking with an operator \\
Velocity analysis & length of 20 ms and an operator white noise label at 0.1 with a picked decon gate \\
Amplitude scaling & Analysis from shot gathers, constant velocity sections with semblance plots \\
Normal move out and sectioning & 10 -ms operator length \\
Migration & With sectioning velocities \\
Time/depth conversion & F-K migration with maximum frequency to migrate of $300 \mathrm{~Hz}$ \\
& Used vertical seismic profiling velocities from the PGW-25B well to generate velocity \\
Import into Kingdom ${ }^{\circledR}$ Suite for & profile \\
interpretation &
\end{tabular}

on the common-offset GPR gathers and to determine EM wave velocities. Seven of these lines were oriented along the geologic strike of the underlying stratigraphy, and two were acquired perpendicularly for a pseudo 3-D control of the ground subsurface. All the GPR antennas were oriented parallel to each other and perpendicular to the survey line to obtain maximum overlap of the radar footprint along the profile (Annan and Davis, 1992). The specifications of the main acquisition parameters are listed in Table 3.

Processing of the GPR transects was performed with the Sensors and Software's, Inc. EKKOView Deluxe ${ }^{\circledR}$ and Landmark Graphics' ProMax ${ }^{\circledR}$ software packages. Most of the assumptions that apply to processing and interpretation of seismic reflection data also apply to surface GPR (Sangree and Widmier, 1979; Yilmaz, 1987, 2001). A general processing flow is detailed in Table 4 and includes the following flow: (1) WOW removal, (2) hand static corrections, (3) bandpass filter, (4) deconvolution, (5) migration, (6) time to depth conversion, and (7) amplitude scaling. The CMP velocities were used to migrate and convert to depth the time sections. Finally, the GPR transects were imported into the Kingdom ${ }^{\circledR}$ Suite software along with the 2-D SSR section, the natural gamma and resistivity logs for a more accurate interpretation.

\section{Crosshole Ground-Penetrating Radar}

The crosshole GPR field data analyzed in this study were collected between each pairs of POS-1, POS-2, and POS-3 wells (Figure 2). The POS-1 and POS-2 wells

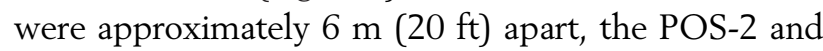

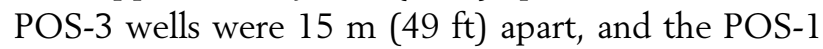

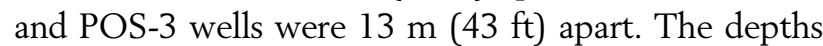
of the wells ranged from 30 (POS-1) to $45 \mathrm{~m}$ (148 ft) (POS-2 and -3). The borehole antennas used for the crosshole survey had center frequencies of 50- and 100-MHz. The 100-MHz antennas were only used between POS-1 and -2 because of the relatively close separation distance between these two wells. The receiver antenna was moved every $0.25 \mathrm{~m}(0.82 \mathrm{ft})$. For each receiver location, the transmitter antenna was fired every $0.25 \mathrm{~m}(0.82 \mathrm{ft})$ as it was raised up the borehole. The resulting data set contains more than 21,000 traces. We only processed those traces where both the transmitter and receiver antennas were located entirely below the water table (based on water-level measurements to be approximately $13 \mathrm{~m}(43 \mathrm{ft}$ ) below the ground surface at the time of the survey).

To account for robust crosshole tomograms, we followed the recommendations provided by Peterson (2001) that include the following corrections: (1) drift 


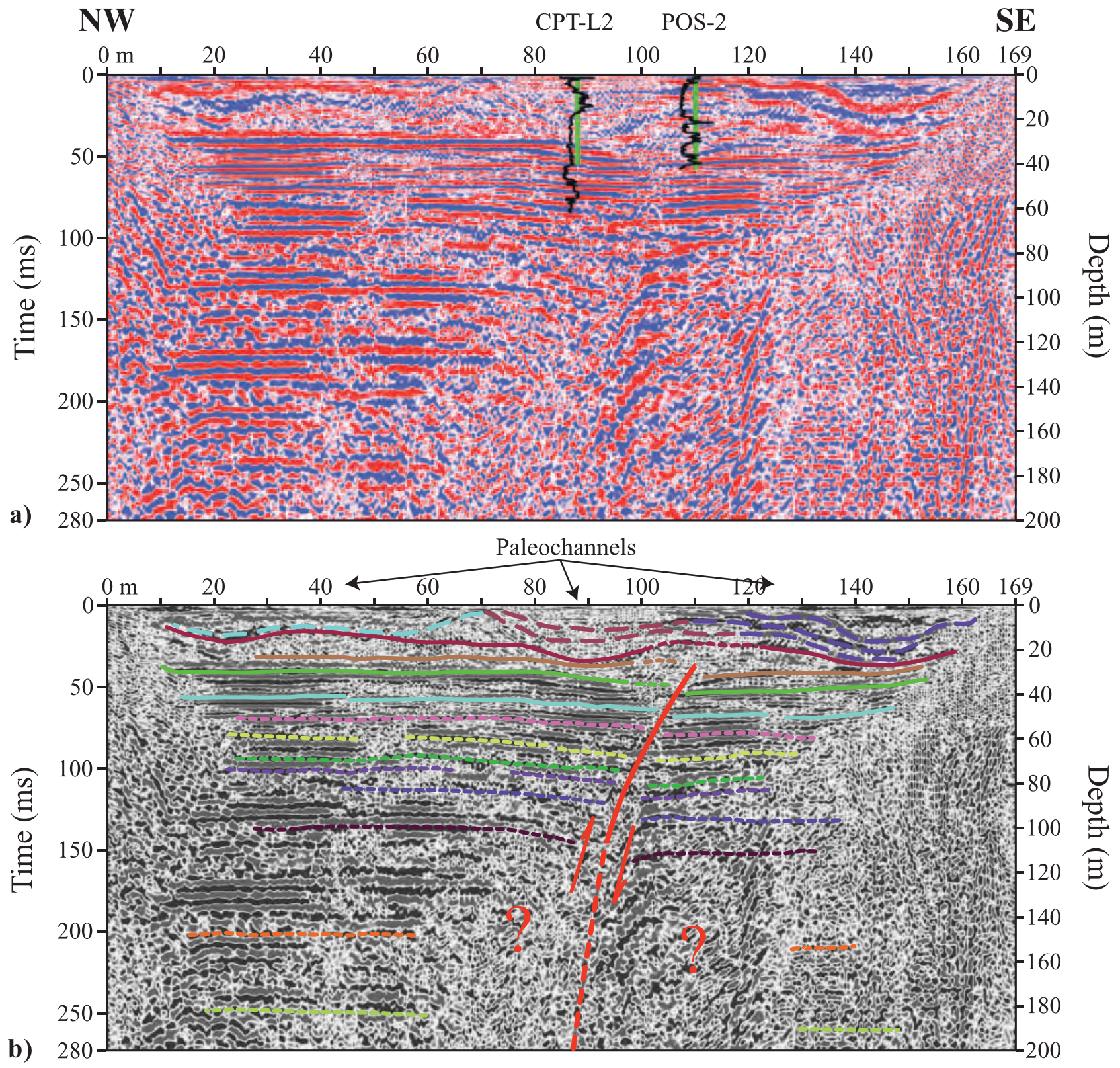

\section{Explanation}

Formation Tops

\begin{tabular}{|c|c|c|c|c|}
\hline Tobacco Road & $\infty$ & Warley Hill & --- & $\begin{array}{l}\text { Lang Syne/Sawdust } \\
\text { Landing }\end{array}$ \\
\hline Dry Branch & $-\infty$ & Congaree & -- & Steel Creek \\
\hline Clinchfield & $\infty$ & Fourmile & --- & Black Creek \\
\hline Santee & $\infty$ & Snapp & $-\infty$ & Middendorf \\
\hline
\end{tabular}

Paleochannel Complexes

- Paleochannel 1

- Paleochannel 2

- Paleochannel 3

Figure 6. An uninterpreted (a) and interpreted (b) part of the shallow seismic reflection profile trending northwest-southeast in the study site confirming the presence of paleochannel complexes in the first $30+\mathrm{m}(98+\mathrm{ft})$ depicted by the cyan, brown, and violet thick dashed lines (from Addison et al., 2009) and suggesting deeper faulting. Electrical resistivity (CPT-L3) and natural gamma (POS-2) logs used to calibrate the radar reflective horizons are also shown. Solid horizons correspond to formation tops from core data. Thin dashed horizons below $60-\mathrm{m}$ (197-ft) depth correspond to formation tops inferred from the geology of the area. The sense of movement of the inverse fault is inferred from the reflectors adjacent to the interpreted fault and may be variable depending upon the amount of inverse motion. Poor resolution at the edges of the cross section is caused by the decreasing of fold coverage. 
Table 3. Survey Parameters for 2-D Surface Ground-Penetrating Radar Acquisition as a Function of the Radar Antenna Frequencies Collected at the Study Site

\begin{tabular}{lcccc}
\hline $\begin{array}{l}\text { Antenna } \\
\text { Frequency }(\mathrm{MHz})\end{array}$ & $\begin{array}{c}\text { Temporal Sampling } \\
\text { Interval }(\mathrm{ps})\end{array}$ & Step Size $(\mathrm{m})$ & $\begin{array}{c}\text { Antenna } \\
\text { Separation }(\mathrm{m})\end{array}$ & $\begin{array}{c}\text { Expected Vertical } \\
\text { Resolution }(\mathrm{m})\end{array}$ \\
\hline 50 & 1600 & 0.5 & 2.0 & $0.5-1.0$ \\
100 & 800 & 0.25 & 1.0 & $0.25-0.5$ \\
200 & 400 & 0.10 & 0.5 & $0.1-0.25$ \\
\hline
\end{tabular}

or discrete jumps in the zero time, (2) transmitter and receiver inaccurate geometry correction, (3) high-angle raypath correction, and (4) picked amplitude correction for geometric and radiation pattern. These corrections and processing steps were applied prior to the inversion of the crosshole data sets.

\section{Electrical Resistivity Imaging}

Surface resistivity is a well-known shallow geophysical tool and has been used in numerous environmental investigations, particularly in unconsolidated sediments (e.g., Pipan et al., 2003; Mota and Monteiro dos Santos, 2006; Wempe and Mavko, 2006). The ERI data collected involved the 2-D Wenner profiling method because the higher signal-to-noise ratio provided a good vertical resolution for subhorizontal layers as expected at this study site (Ward, 1990; Wyatt et al., 1996). Four Wenner configuration transects were acquired at the study site to provide a pseudo
3-D resistivity subsurface characterization (Figure 5). The same electrode configuration $(4-\mathrm{m}$ [13-ft] spacing) was used for each transect to improve the field logistics and to decrease the acquisition time.

\section{RESULTS}

The coincident use of the SSR and ERI methods in conjunction with the complementary GPR data using the 50-, 100-, and 200-MHz antennas allowed us to perform a detailed shallow stratigraphic characterization of the study site that is further needed for the contaminant plume geometry characterization and migration pathways. For the purpose of this study, we focused our characterization efforts in the upper $45 \mathrm{~m}$ (148 ft) of the ground subsurface where the TCE concentration is located (Figure 4). The water table depth during the geophysical surveys varied roughly between 12 and $14 \mathrm{~m} \mathrm{(39}$ and $46 \mathrm{ft}$ ) below the ground surface.

Table 4. Generalized Processing Diagram for Surface Ground-Penetrating Radar Data

Processing

Parameter

Download from GPR unit

Import into EKKOView Deluxe ${ }^{\circledR}$

WOW removal

Reformat to SEGY

Removed unwanted electrostatic low frequency noise

Import into ProMax ${ }^{\circledR}$

Hand static corrections

Bandpass filter

Deconvolution

Used to specify and apply static shift corrections

Single filter Ormsby bandpass, corner frequencies varied with the antenna frequency used Spiking/predictive deconvolution using minimum-phase spiking with an operator length of 4 ns and an operator white noise label at 0.001 with a picked decon gate

Migration

Time/depth conversion

Amplitude scaling

Import into Kingdom ${ }^{\circledR}$ Suite

Interval velocity in time from CMP gathers

Used CMP gather velocities

10-ns operator length

for interpretation 
The results of each geophysical technique were compared against and calibrated with the CPT and natural gamma logs.

\section{Cone Penetrometer Tests and Natural Gamma Logs}

Figure 4 shows a hydrogeologic cross section derived from the CPT and natural gamma logs in conjunction with the hydrostratigraphic units and hydrogeologic facies identified in the study area. The CPT curves L-1, L-2, and L-3 represent one-dimensional sleeve and tip friction, pore-pressure and electrical resistivity curves showing the sediments' shear strength, effective stress, and ability to conduct electrical current scaled in units of ohm meters. Natural gamma curves POS-1, -2, and -3 show the difference in radioactivity in counts per second between clays and sands. Both techniques showed good vertical resolution down to about 45-m (148-ft) depth. Changes in the electrical resistivity logs (CPT-L1, -L2, and -L3 wells) suggest a strong hydrologic change at approximately $13 \mathrm{~m}(43 \mathrm{ft})$, which was interpreted to be the water table. Based on a previous SRNL interpretation, the seven major hydrogeologic facies within the UTRA (i.e., vadose zone, upper sand, upper clay, middle sand, middle clay, lower sand, and lower clay) appear to be laterally continuous across the study area.

\section{Shallow Seismic Reflection Data}

The SSR data imaged well-defined subhorizontal reflectors from the surface to about $280 \mathrm{~ms}$ (200-m [656-ft] depth) (Figure 6). This part of the section represents the shallow UACP stratigraphy. Shallow formation tops were interpreted in correlation with the core data down to about 45-m (148-ft) depth. Deeper formation tops were interpreted from correlation with data presented in the literature (Fallaw and Price, 1995). These Tertiary formations range in age from early Paleocene to Miocene and were deposited in fluvial to marine shelf environments (Wyatt et al., 2000). The Tertiary sequence is divided into three groups, the Black Mingo Group, Orangeburg Group, and Barnwell Group, which are further subdivided into formations and members (Figure 2). These groups are overlain by the ubiquitous Upland unit.

Some of the significant findings from the SSR data include (1) a series of, at least three, paleochannel structures in the first $30+\mathrm{m}(98+\mathrm{ft}),(2)$ the hydrogeologic facies do not appear to be as continuous as previously thought by SRNL, and (3) the presence of a prominent near-vertical discontinuity in the subhorizontal reflectors at approximately $100-\mathrm{m}(328-\mathrm{ft})$ distance from the northwestern end of the line that propagates from above about $25 \mathrm{~m}(82 \mathrm{ft})$ down to the bottom of the section and potentially to the crystalline basement. The three paleochannels were interpreted on the seismic section and they appear to incise the top of the Tobacco Road Formation (cyan, brown, and violet thick dashed lines in Figure 6b). Moreover, these paleochannel structures coincide with those imaged and documented by Addison et al. (2009). Based on the cross section derived from the CPT and natural gamma logs (Figure 4), the hydrogeologic facies appear to be continuous laterally across the study area. However, through a closer look, the upper sand, upper clay, and middle sand appear to be interspersed and truncated to one another. The imaged discontinuity is consistent with the interpretation of an inverse fault and appears to be associated with about $5-\mathrm{m}$ (16-ft) vertical offsets in the reflectors (Figure 6b). The key shallow horizons imaging displacements up to approximately $5 \mathrm{~m}(16 \mathrm{ft})$ correspond to the Dry Branch Formation in the upper section through the Steel Creek Formation toward the bottom, thus, making the fault upper Eocene in age. The steeply dipping events imaged on the southeastern half of the seismic section may be diffractions from the fault plane.

\section{Surface Ground-Penetrating Radar}

Besides the SSR section, the surface GPR sections provided higher resolution and coherent reflectors for the first $16 \mathrm{~m}(52 \mathrm{ft})$ of the study site. The surface GPR data were converted from time to depth using interval velocity information provided by CMP gathers collected at the site (Figure 7). From the CMP survey, the EM velocity increases from $0.08 \mathrm{~m}(0.26 \mathrm{ft}) / \mathrm{ns}$ at $50 \mathrm{~ns}$ twoway traveltime (TWTT) to $0.09 \mathrm{~m}(0.29 \mathrm{ft}) / \mathrm{ns}$ at $225 \mathrm{~ns}$ TWTT, then decreases from $0.09 \mathrm{~m}(0.29 \mathrm{ft}) / \mathrm{ns}$ at $225 \mathrm{~ns}$ TWTT to $0.072 \mathrm{~m}(0.23 \mathrm{ft}) / \mathrm{ns}$ at $400 \mathrm{~ns}$ TWTT and from $0.05 \mathrm{~m}(0.16 \mathrm{ft}) / \mathrm{ns}$ at $650 \mathrm{~ns}$ TWTT to $0.04 \mathrm{~m}$ $(0.13 \mathrm{ft}) / \mathrm{ns}$ at $750 \mathrm{~ns}$ TWTT. The propagation velocity of EM waves is a function of the dielectric constant of the subsurface, which in turn is affected by the water content. The subsurface reflections from the interfaces between layers with contrasting dielectric constants appear as hyperbolic events in the CMP section, whereas the air and ground waves are imaged as straight lines in the uppermost part of the CMP gather (Figure 7a). 


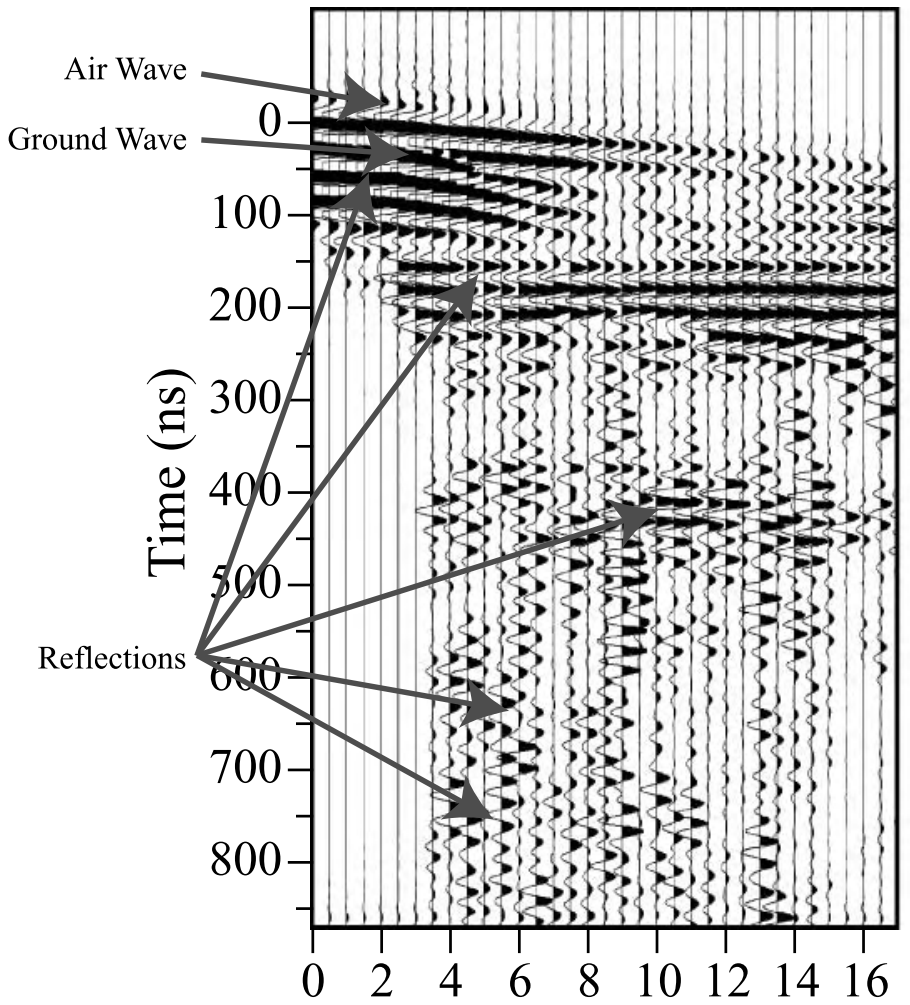

a)
Position (m)

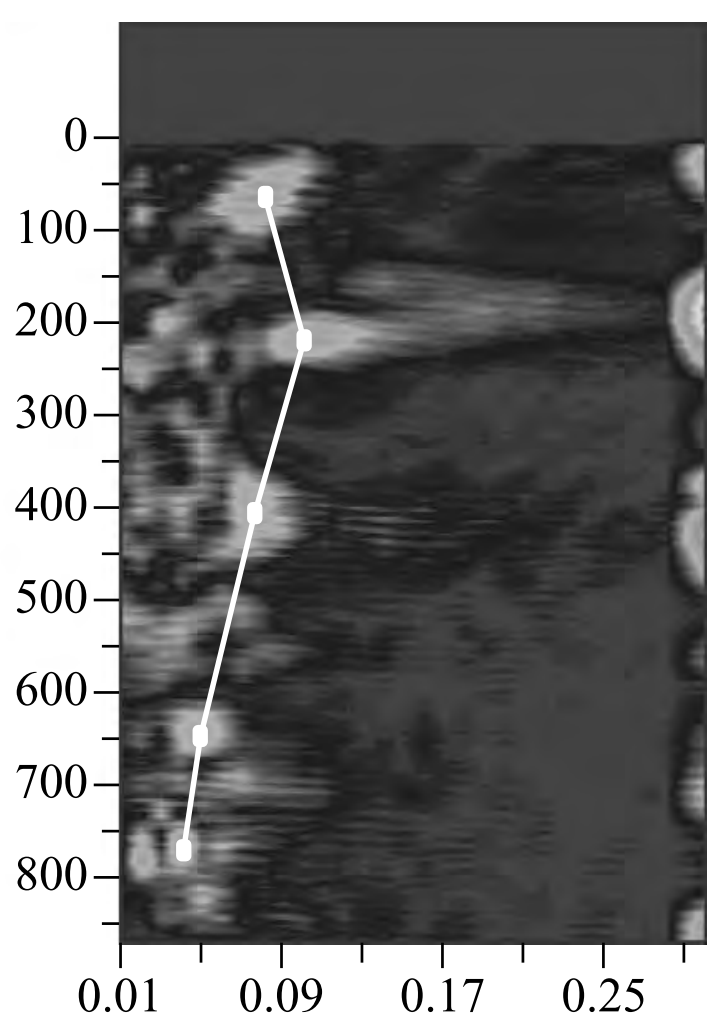

b)

\section{Velocity $(\mathrm{m} / \mathrm{ns})$}

Figure 7. (a) Common-midpoint (CMP) radar gather at the study site. The uppermost two events are the air wave and the ground wave that appear to be highly attenuated beyond a horizontal distance of $10 \mathrm{~m}(33 \mathrm{ft})$. Subsurface reflectors are represented by hyperbolas. (b) Velocity profile derived from the CMP gather. Velocity is incremented in $0.001-\mathrm{m}(0.003-\mathrm{ft}) / \mathrm{ns}$ steps from 0.01 to $0.29 \mathrm{~m}(0.03$ to $0.95 \mathrm{ft}) / \mathrm{ns}$. Dots indicate picked points of maximum coherence that define the velocity profile.

This characteristic shape is based on the assumption that the arrival time for signals from reflectors varies hyperbolically with the separation between the trans- mitter and the receiver antenna. The poor reflection quality may indicate that the energy is highly attenuated with depth. Figures 8, 9, 10, and 11 show some

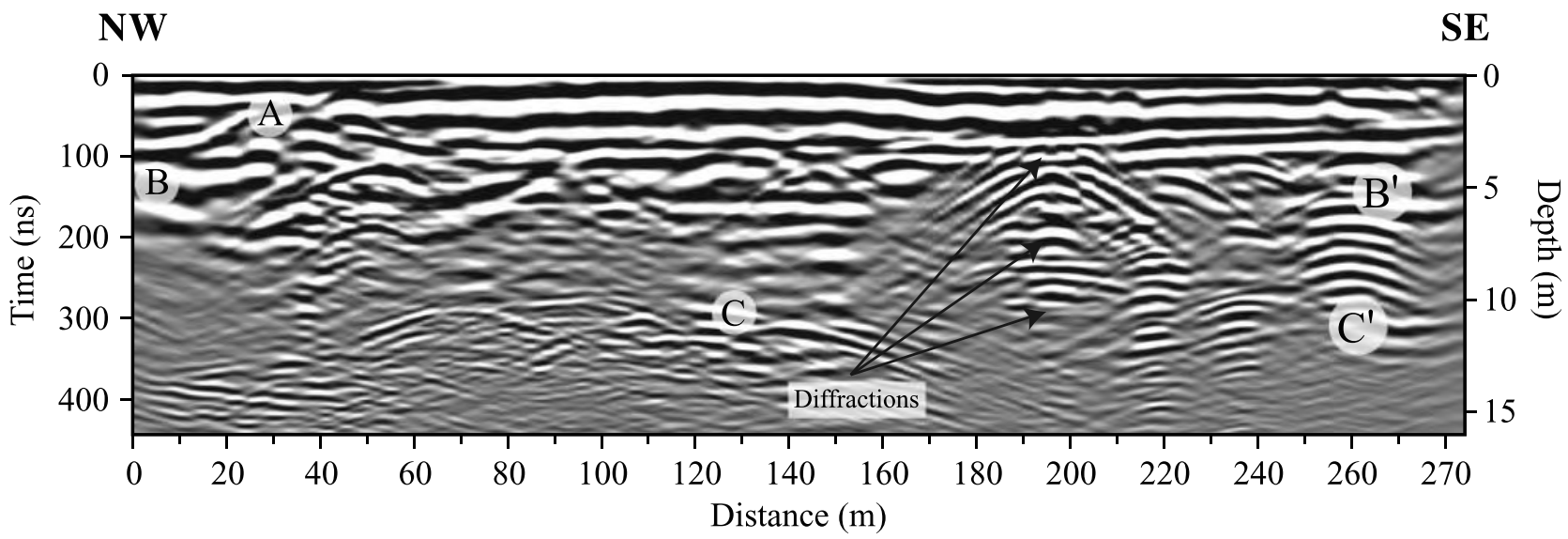

Figure 8. The GPR 50-MHz section (L-1) from the study site. Reflections are evident down to approximately 5-m (16-ft) depth along the northwestern end of the section. Diffractions appear to occur at 3- to 10-m (10- to 33-ft) depth. Reflections discussed in the text are labeled $A, B$, and $C$. 


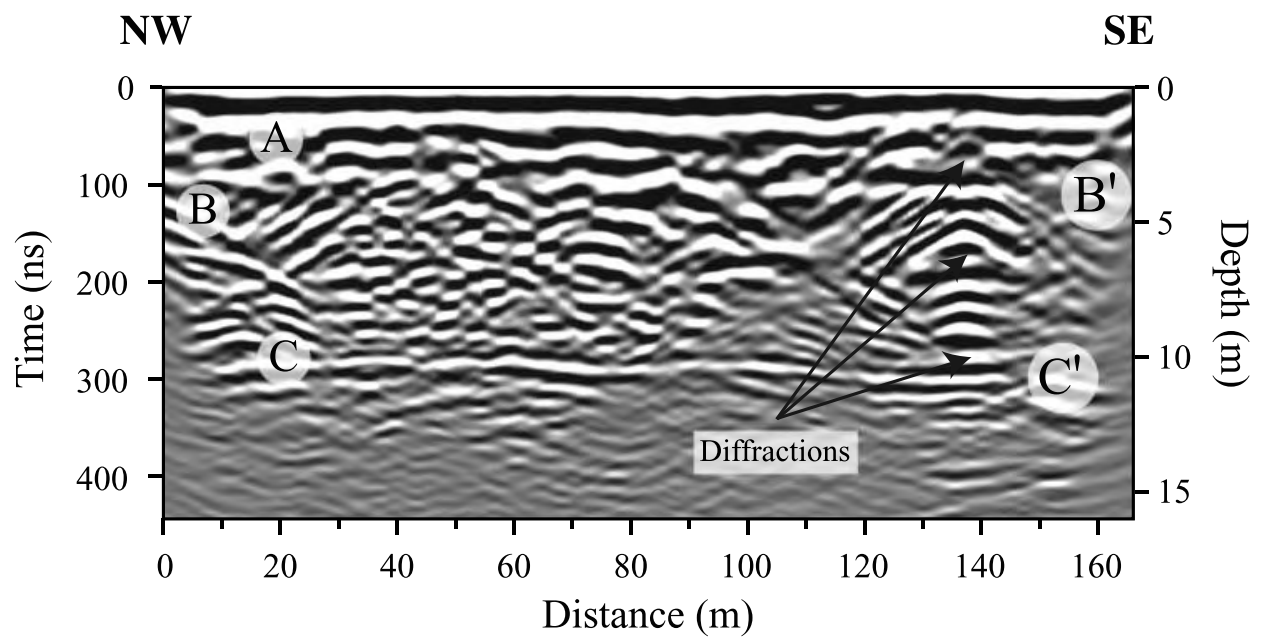

Figure 9. The GPR 50-MHz section (L-3) from the study site. Reflections are evident to 12-m (39-ft) depth along the section (e.g., A, BB', and $\left.C C^{\prime}\right)$. The strong reflection labeled $C$ at $12-\mathrm{m}$ (39-ft) depth belongs to the water table. Note diffraction hyperbolas at 3- to $10-\mathrm{m}$ (10- to 33-ft) depth.

of the surface GPR surveys collected at the study site. Positions of these GPR lines are parallel with the locations of the CPT and POS wells. Line L-1 is shown in Figure 8. Strong coherent reflectors (A) are imaged from about $50 \mathrm{~ns}$ TWTT (3-m [10-ft] depth) on the northwestern side to about 100 ns TWTT (4-m [13-ft] depth) in the southeast. The EM energy is highly attenuated between approximately 200 and 300 ns TWTT (7-11-km [4.3-6.8-mi] depth). At 195-m (640-ft) distance from the northwestern end of the line, some diffractions occur with an apex at about 100 ns TWTT (e.g., 4-m [13-ft] depth). A reflector (B) at 150 ns TWTT (5-m [16-ft] depth) at the northwestern end appears on the profile at approximately $170-\mathrm{m}(558-\mathrm{ft})$ distance. A strong reflector $\left(\mathrm{B}^{\prime}\right)$, similar to reflector $\mathrm{B}$, starts at about 250-m (820-ft) distance. A weakly co- herent reflector (C) can be noticed at approximately $300 \mathrm{~ns}$ TWTT (12-m [39-ft] depth) in the $150 \mathrm{~m}$ (492 ft) of the section. The reflector ends at the same distance as reflector $\mathrm{B}$. Other reflectors can be seen between approximately 300 and 400 ns TWTT to the southeast of $180-\mathrm{m}(590-\mathrm{ft})$ distance, but they are not as coherent laterally but of poorer quality.

Line L-3 (Figure 9) is parallel to but approximately $40 \mathrm{~m}$ (131 ft) apart of line L-1 (Figure 8). The data quality for these two $50-\mathrm{MHz}$ lines is very similar. Thus, the strong coherent reflectors labeled A in line L-1 are also interpreted on line L-3 but deeper in the section at about $300 \mathrm{~ns}$ TWTT compared to about $50 \mathrm{~ns}$ TWTT in L-1. Reflector B is highly disrupted by diffractions that occur at $140-\mathrm{m}(459-\mathrm{ft})$ distance. However, reflector $\mathrm{C}$, interpreted as the water table, appears

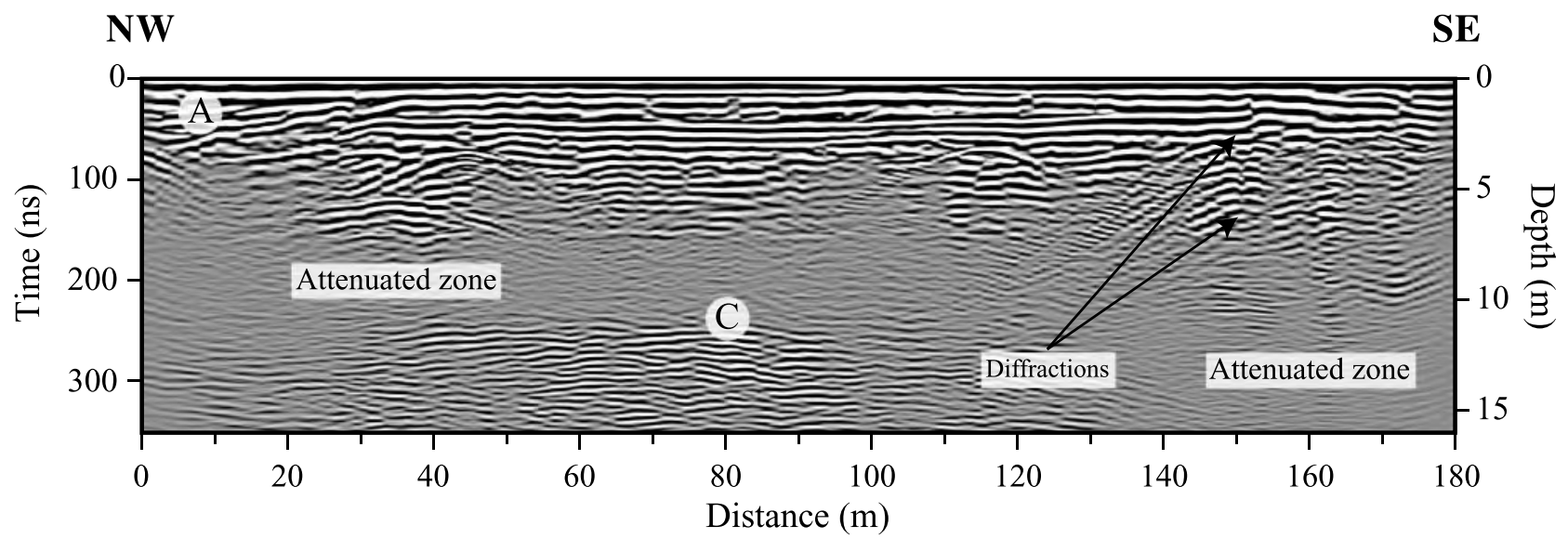

Figure 10. The GPR 100-MHz section (L-6) from the study site. The reflectors labeled $A$ are strong, coherent, and continuous along the section. Weak reflectors at about 150 to $250 \mathrm{~ns}$ TWTT (7- to 12-m [23- to 39-ft] depth) at the northwestern side of the section indicate that the energy is attenuated. Label $\mathrm{C}$ denotes the water table reflector at about 12-m (39-ft) depth seen at every surface GPR line. Diffractions occur at 3- to 7-m (10- to 23-ft) depth. 


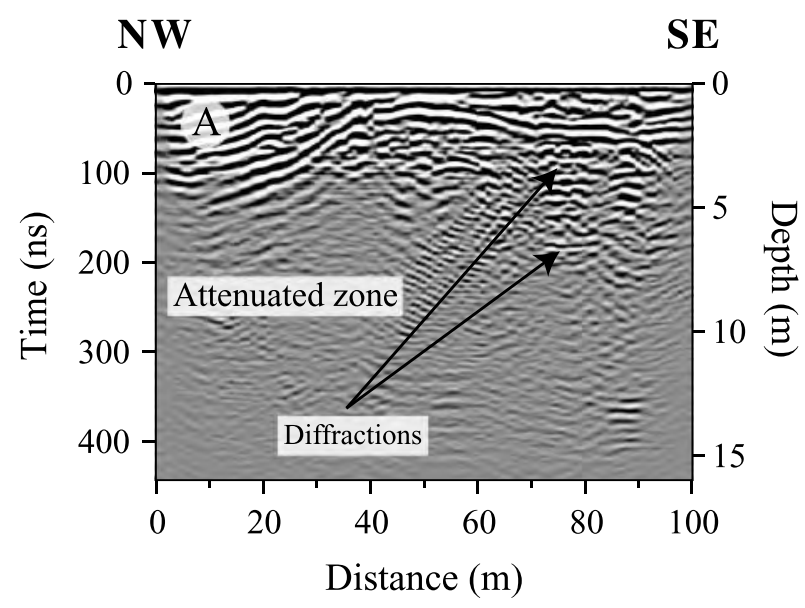

Figure 11. The GPR 100-MHz section (L-6) from the study site. The reflector package labeled $A$ indicates a possible paleochannel structure that may correspond to that interpreted on the 2-D SSR section. Diffractions occur at about 50 and 150 ns TWTT ( 3to $7-\mathrm{m}$ [10- to $23-\mathrm{ft}]$ depth). The energy is strongly attenuated at times greater than approximately 125 ns TWTT (4-m [13-ft] depth).

to be strong, coherent, and continuous along the acquired section.

The surface GPR data quality decreased significantly upon increased antenna frequency. Figure 10 is a GPR section collected at the study site with the center antenna frequency of $100 \mathrm{MHz}$ (line L-6). Poor depth penetration was expected due to the increasing frequency, but surprisingly, this GPR line shows prominent reflectors down to $16 \mathrm{~m}(52 \mathrm{ft})$ below the ground surface. The reflector package A seems to be stronger and more coherent than the same interpreted reflectors in lines L-1 and L-3 (Figures 8, 9). However, poor reflectivity contrast is seen at approximately 150 to $250 \mathrm{~ns}$ TWTT (7- to 12-m [23- to 39-ft] depth) in the northwestern side of the section. A strong reflection package is seen below approximately $220 \mathrm{~ns}$ (12 m [39 ft]) in the northwestern half of the section that is truncated laterally at about 130-m (426-ft) distance. Some diffractions are visible at $150-\mathrm{m}$ (492-ft) distance and about 50 to $150 \mathrm{~ns}$ TWTT (3- to $7-\mathrm{m}$ [10- to 23-ft] depth). The diffraction tails are shorter and of weaker amplitude than those in lines L-1 and L-3 (Figures 8, 9). Beneath these diffractions, the energy is strongly attenuated at times greater than approximately $150 \mathrm{~ns}$ TWTT (7-m [23-ft] depth).

Line L-10 (Figure 11) was also collected with the $100-\mathrm{MHz}$ antennas. A paleochannel structure is evident at $\mathrm{A}$ and appears to be strong, coherent, and con- tinuous through the section. Diffractions occur at 78-m (256-ft) distance at about 50 and 150 ns TWTT (3- to 6-m [10- to 20-ft] depth). The energy is strongly attenuated at times greater than approximately $125 \mathrm{~ns}$ TWTT (4-m [13-ft] depth). The water table reflector is not obvious in this section.

Geophysical and core data from CPT L-1, L-2, and L-3, and POS wells $-1,-2$, and -3 were used to calibrate the radar reflective horizons; however, other than reflectors $\mathrm{A}, \mathrm{B}$, and $\mathrm{C}$ that appear to be more coherent on the GPR lines, interpreting other deeper, coherent reflectors is difficult. The poor reflectivity contrast between some TWTT intervals throughout the surface GPR sections may be caused by the high clay content interfingered with sands that attenuated the radar signal. Additionally, anomalous or discontinuous reflection zones may be caused by changes in the dielectric constants and/or subsurface conductivity.

\section{Crosshole Ground-Penetrating Radar}

The tomographic analysis of the crosshole data used the raypath length of precise measurements of one-way traveltime to determine the velocity structure of the intervening materials. The inversions of the crosshole GPR data resulted in plots of EM wave velocity, attenuation, and conductivity. Because of the limited depth of the POS wells ( $\sim 30-45 \mathrm{~m}$ [98-148 ft]), we only produced reliable tomograms for the upper $36 \mathrm{~m}$ (118 ft) of the wells (Figures 12, 13). Low EM wave velocity or higher attenuation is characteristic to high porosity and/ or volumetric water content across the plane of investigation. Five hydrogeologic facies were interpreted on the tomograms between POS-1 and POS-2 and were subsequently compared against the CPT and natural gamma logs (Figure 12). The vadose zone in the UAZ approximately corresponds to the upper $13 \mathrm{~m}(43 \mathrm{ft})$ of the wells. The upper sand is approximately $8 \mathrm{~m}$ (26 ft) thick and correlates well with the CPT and natural gamma log data. The TCCZ with upper clay appears to be very thin (less than $2 \mathrm{~m}$ [6 ft]), the middle

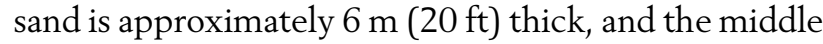
clay is approximately $5 \mathrm{~m}(16 \mathrm{ft})$ thick and appears to dip toward the southeastern edge of the study site.

The tomographic inversion for the POS-1 and POS-3 wells (Figure 13) looks very similar to that of the POS-1 and POS-2 wells. The vadose zone of the UAZ corresponds to the upper $13 \mathrm{~m}(43 \mathrm{ft})$. The up-

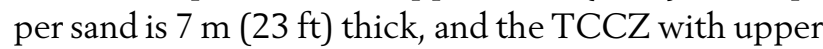



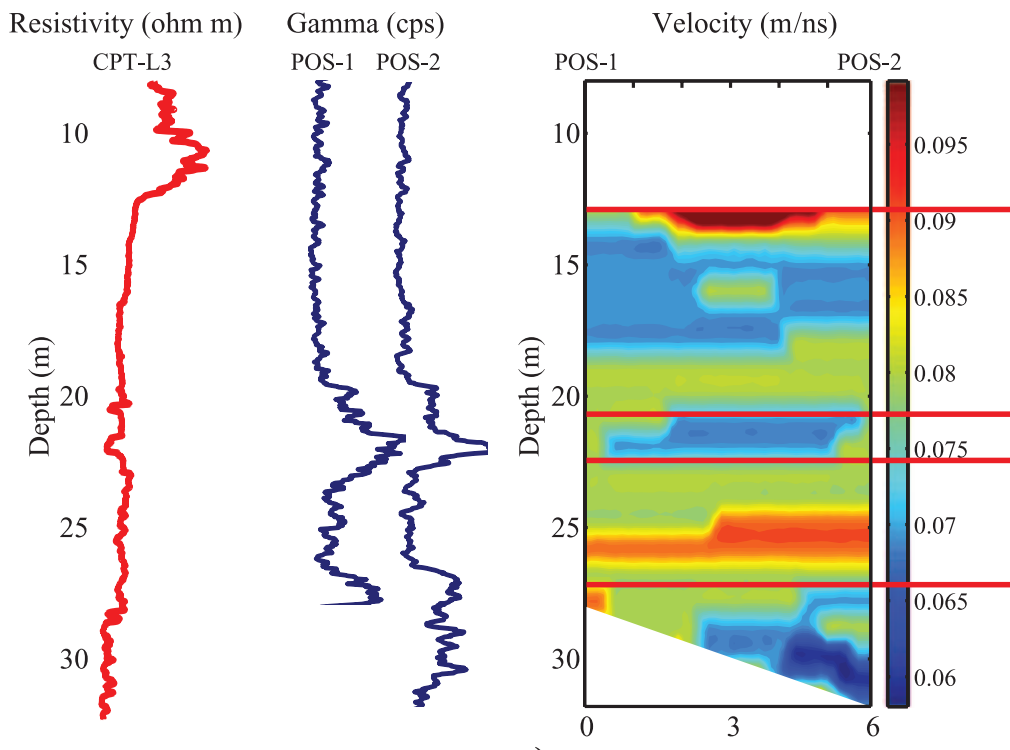

a)

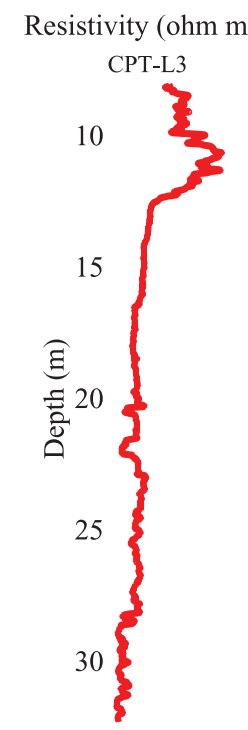

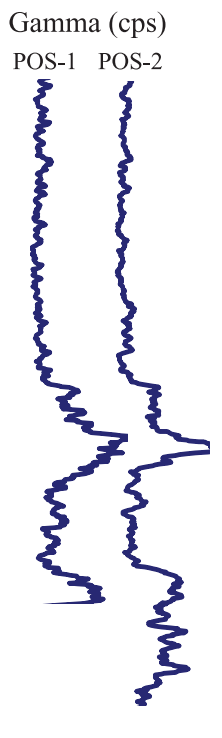

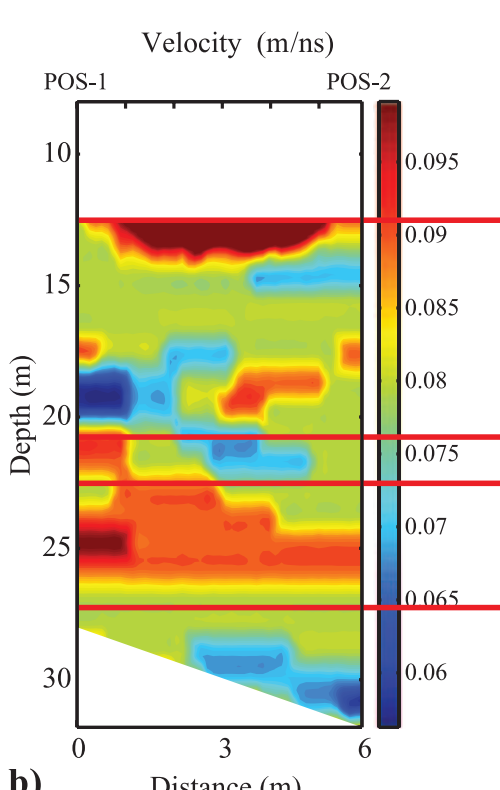

b)
Attenuation $(\mathrm{dB} / \mathrm{m})$

POS-2

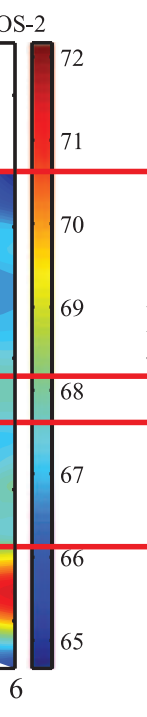

Distance (m)

Attenuation (dB/m) $-1$ S-

POS-2

200 Vadose Zone

180

Upper Sand 160

Upper Clay

Middle Sand

Middle Clay

Distance $(\mathrm{m})$

Conductivity (ms/m)

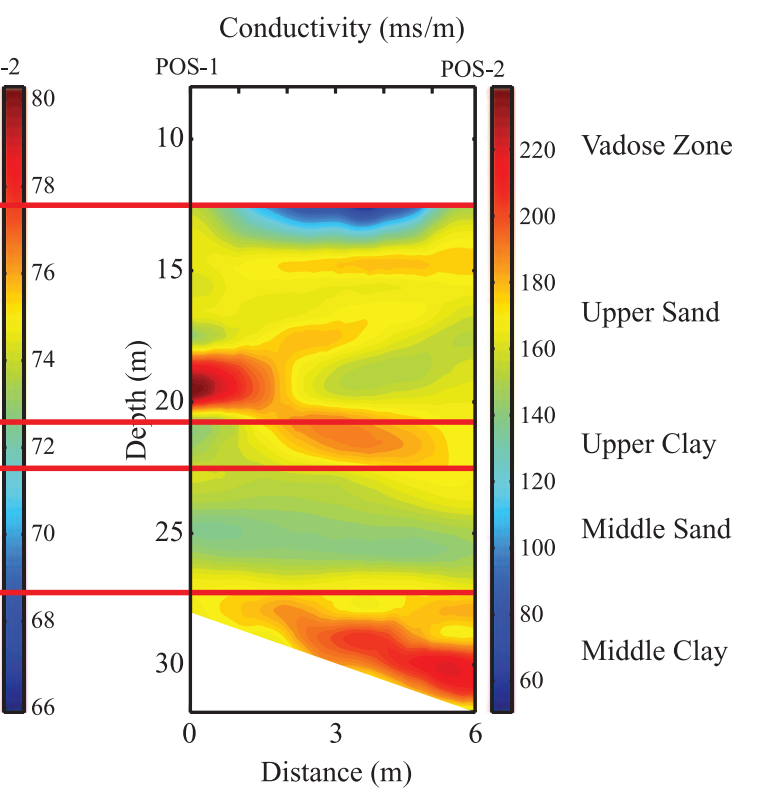

Figure 12. The $50-\mathrm{MHz}$ (a) and 100-MHz (b) crosshole radar EM wave velocity, attenuation, and conductivity tomography plots between POS-1 (Tx) and POS-2 (Rx), showing interpreted hydrogeologic facies (i.e., vadose zone, upper sand, upper clay, middle sand, and middle clay) from data sets collected with the PulseEKKO 100 GPR system. The inverted tomograms were subsequently compared against electrical resistivity (CPT-L3) and natural gamma (POS-1 and -2) logs. The middle clay appears to dip toward the southeastern edge of the study site. 

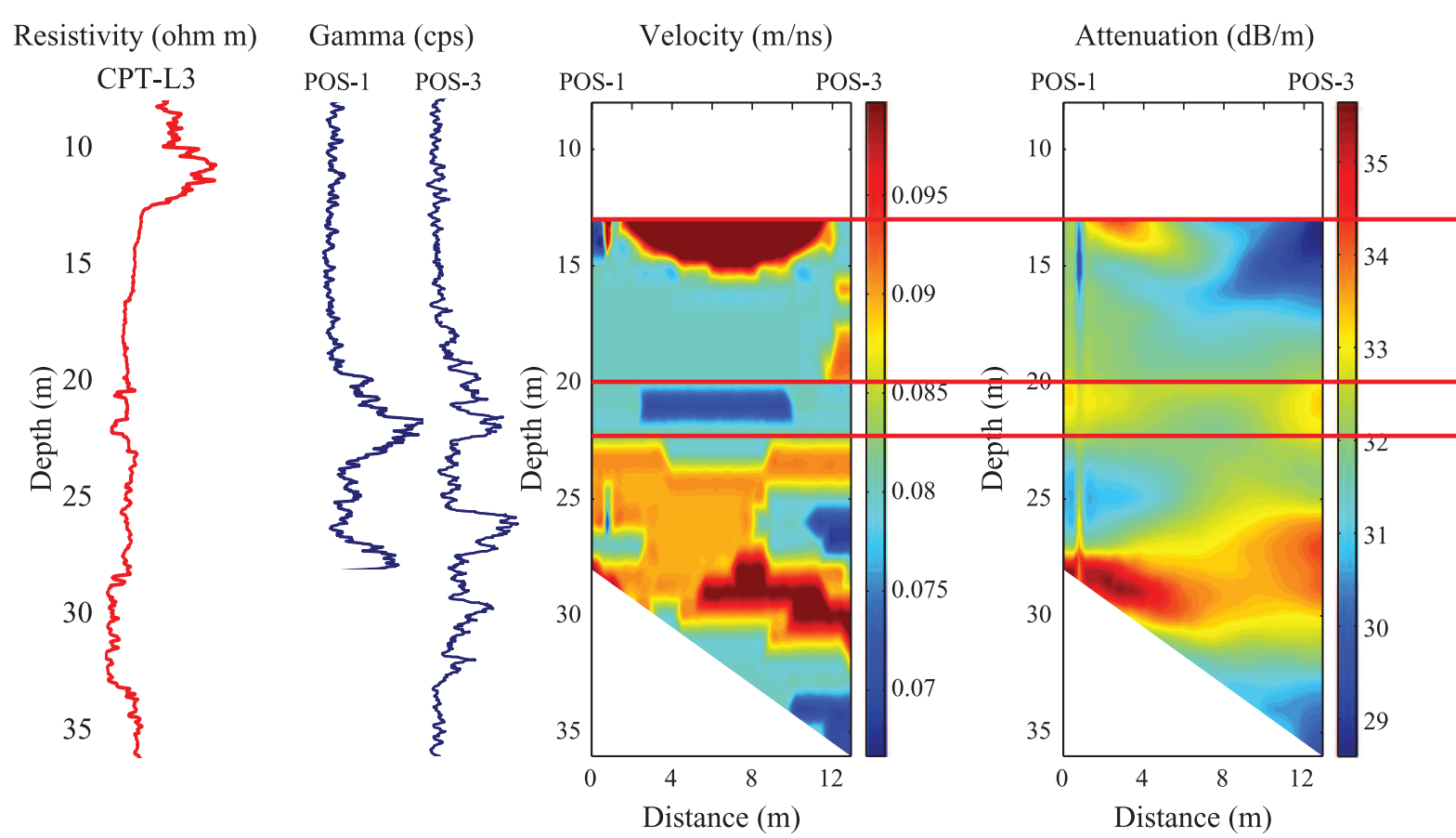

Conductivity $(\mathrm{ms} / \mathrm{m})$

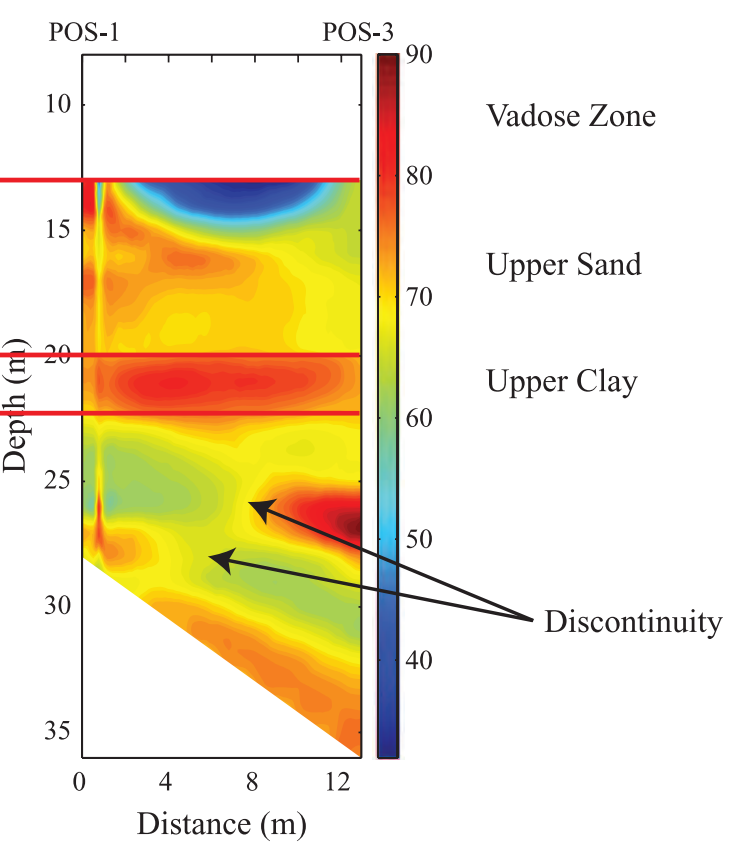

Figure 13. The 50-MHz crosshole radar EM wave velocity, attenuation, and conductivity tomography plots between POS-1 (Tx) and POS-3 (Rx). The inverted tomograms were subsequently compared against electrical resistivity (CPT-L3) and natural gamma (POS-1 and -2) logs. Note the prominent near-vertical discontinuity in the conductivity tomogram stating at 23-m (75-ft) depth. 

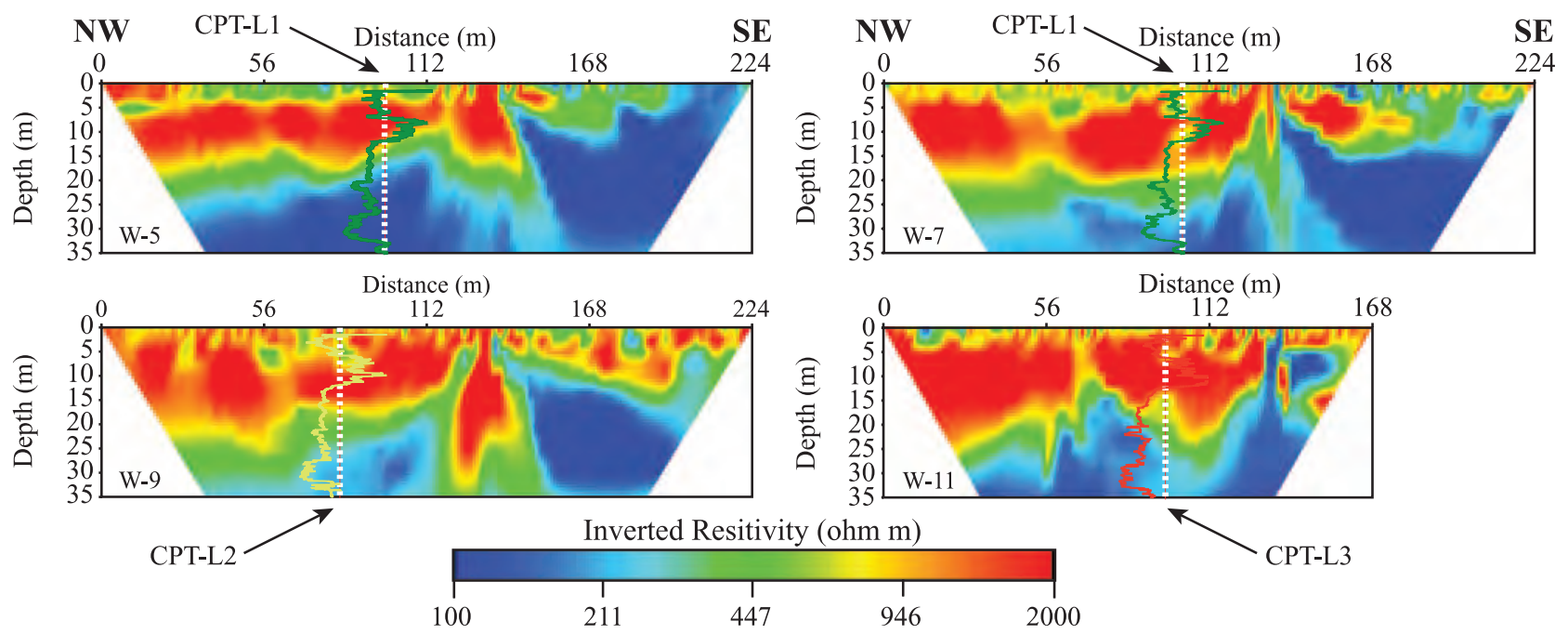

Inverted Resitivity (ohm m)

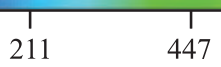

$946 \quad 2000$

Figure 14. Comparison of the Wenner resistivity data with the CPT resistivity logs. Apparent resistivity values have been calibrated with CPT resistivity logs. Note the vertical low-resistivity discontinuity on each profile.

clay appears to be $2 \mathrm{~m}(6 \mathrm{ft})$ thin. However, below approximately $23-\mathrm{m}(75-\mathrm{ft})$ depth, the middle sand and middle clay layers appear to discontinue. This significant discontinuity zone is delineated by the abrupt change in velocity, attenuation, and conductivity between the POS-1 and POS-3 wells (Figure 13) and it appears to correlate spatially with the discontinuity interpreted to be an inverse fault on the SSR section and/or the edge of a paleochannel.

\section{Electrical Resistivity Imaging}

The four electrical resistivity profiles collected at the study site with the Wenner array configuration provided high quality images down to about $35 \mathrm{~m}$ (115 ft) (Figure 14). The CPT logs were superimposed on the resulting resistivity tomograms as seen in Figure 14. The CPT resistivity logs correlate very well with the resistivity tomograms. The data along lines $\mathrm{W}-5, \mathrm{~W}-7$, $\mathrm{W}-9$, and $\mathrm{W}-11$ were collected in parallel directions to the surface GPR and SSR surveys (Figure 5). The lengths of the lines were about 224 (W-5, W-7, and $\mathrm{W}-9)$ and $168 \mathrm{~m}(\mathrm{~W}-11)$ (735 and $551 \mathrm{ft})$. The resulting images along these profiles suggest resistivity values in the range of 100-2000 ohm $\mathrm{m}$ and show approximately subhorizontal and layered resistivity from near the surface down to about $35 \mathrm{~m}$ (115 ft). The water table is not directly observable but may be inferred from the change in resistivity values and correlation with the CPT data at approximately 13-m (43-ft) depth.

High resistivity values are generally seen between approximately 5- and 20+-m depth on each image.
They belong to the vadose zone and the upper sand in the UAZ. Lower resistivity values are observed below 20-m (66-ft) depth, but this could be a response of the increased moisture content due to the saturated zone and/or variations of clay and sand contents within the study site. However, a significant nearly vertical anomaly, which propagates throughout all four recorded lines, is observed at about $125-\mathrm{m}$ (410-ft) distance along the profiles. This anomaly propagates from near the surface to large depths and is characterized by rapid changes of several hundreds of thousands of ohm meters in the shallow data. This discontinuity is associated with low resistivity (high conductivity) and marks a sharp change in the subhorizontal resistivity values across it. Moreover, this discontinuity approximately corresponds with the projected position of the discontinuity imaged on the SSR data, making it a potential candidate for a steeply dipping inverse fault as interpreted before.

\section{INTERPRETATION}

Although a detailed stratigraphic layering was identified and interpreted in the upper approximately $50 \mathrm{~m}$ $(164 \mathrm{ft})$ of the subsurface at the study site using various geophysical techniques, to constrain the TCE plume geometry and how it may relate to the structural geology of the subsurface, a direct correlation among the individual geophysical surveys was performed (Figure 15). In Figure 15, the crosshole GPR, electrical 


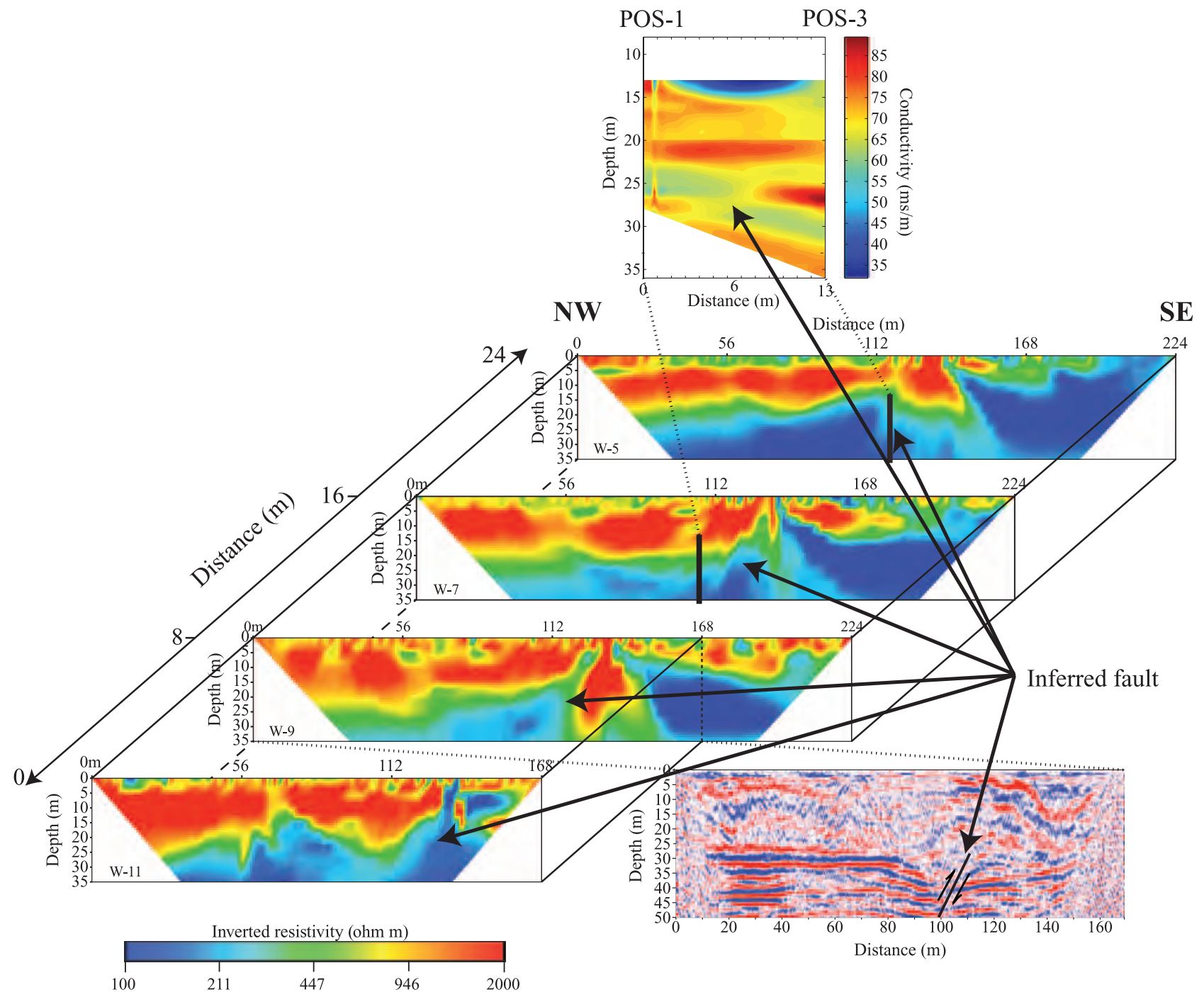

Figure 15. The $50-\mathrm{MHz}$ crosshole radar EM wave conductivity tomogram (POS-1 and POS-3), electrical resistivity Wenner sections $(\mathrm{W}-5,-7,-9$, and -11$)$, and the upper $50 \mathrm{~m}(164 \mathrm{ft})$ of the 2-D SSR section correlation. Black arrows correspond to the interpreted inverse fault as described in the text.

resistivity, and seismic sections are shown at the same scale and are geographically aligned. As seen in this Figure 15, the position and orientation of the discontinuity interpreted on the seismic line seem to correlate well spatially with the discontinuity mapped on the resistivity profiles as well as the dipping feature in the crosshole radar tomograms, thus making it a strong candidate for a fault. Based on the seismic line, this inferred fault appears to have an inverse movement and is interpreted with a higher level of certainly below $23 \mathrm{~m} \mathrm{(75} \mathrm{ft)} \mathrm{from} \mathrm{the} \mathrm{ground} \mathrm{surface.} \mathrm{Some} \mathrm{of} \mathrm{the} \mathrm{geo-}$ logical and geophysical constraints of the interpreted inverse fault include the following: (1) the seismic image shows reverse movement, consistent with coastal plain faults (Higgins et al., 1978; Zoback et al., 1978;
Behrendt et al., 1983; Hamilton et al., 1983; Schilt et al., 1983; Talwani, 1986; Shedlock and Harding, 1988; Snipes et al., 1993; Wyatt and Temples, 1996; Wyatt et al., 1996), (2) the interpreted position of the fault is consistent with the discontinuity mapped on the crosshole GPR tomograms between POS-1 and POS-3 as well as with the high-conductivity anomalies on the coincident resistivity profiles, and (3) the electrical resistivity changes greatly laterally across the high-conductivity anomaly. Although, based on the seismic profile, one can argue that the fault continues farther to the surface, however, the crosshole tomograms between POS-1 and POS-3 suggest that the interpreted fault stops at about 23-m (75-ft) depth. This interpretation makes the fault upper Eocene or older. 
$81.35^{\circ} \mathrm{N}$

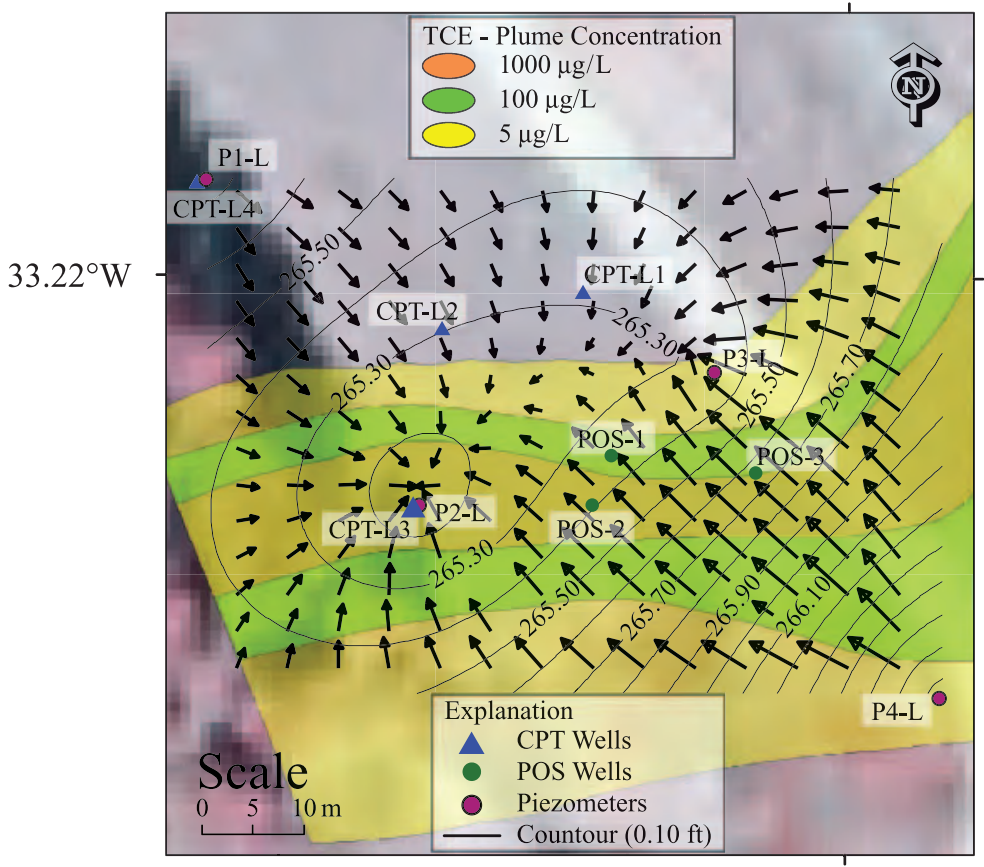

$81.35^{\circ} \mathrm{N}$
Figure 16. Potentiometric surface map with the hydraulic gradient changing across the study site. Note the convergence of groundwater flow near the area west of the position (POS) wells. CPT = cone penetrometer tests; TCE = trichloroethylene.
The three paleochannels imaged in the SSR section appear to have a control on the shape and migration direction of the TCE plume. Addison et al. (2009) indicated that the paleochannel complexes at the study site are acting as conduits for the plume migration, thus, the slight turn of the plume to the south-southwest near the POS wells. However, the hydraulic gradient calculated from potentiometric surface data between the piezometers (mapped in Figure 2) indicates a convergence of groundwater flow near the area west of the POS wells (Figure 16). This area of convergence appears to be within the paleochannel 2 imaged in the SSR section and by Addison et al. (2009). The groundwater flow, in a local spatial scale, could possibly have a preferred pathway trough paleochannel 2 , hence, the plume narrowing down away from the source and flow updip stratigraphic bedding.

Interpretation and analysis of the surface GPR sections provide a detailed image of the overall internal structure and depositional patterns recorded within the sediments in the upper $16 \mathrm{~m}(52 \mathrm{ft})$ of a dynamic modern channel system (reflector packages A and B in Figures 8-11). From the surface GPR data, we can compare and correlate the channels with those in the SSR section and in Addison et al. (2009) to develop a relative explanation of the depositional processes that control the channel growth and modification with respect to the fault. Close observation of the surface GPR and SSR sections shows that the vertical offsets in the seismic data occur beneath the interpreted paleochannels. This fault may be the cause of the paleochannel growth, modification, and shape due to inverse faulting in the earliest stages of the paleochannels formation, which could have provided control on the structural evolution of the channels.

Based on a synthesis of all of the geophysical methods used in this study, an interpretive geologic model was generated and shown in Figure 17. Interpreted off-

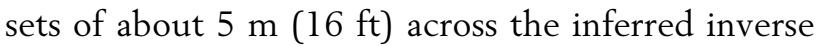
fault are consistent with published literature that indicates faulting in the coastal plain sediments to be post Late Cretaceous. These faults generally exhibit the following features: (1) offsets of about $5 \mathrm{~m} \mathrm{(16ft)} \mathrm{close} \mathrm{to}$ the surface, (2) strike orientation in the northeasternsouthwestern quadrant with reverse movement, and (3) movement beginning in the Cretaceous and decreasing with time (Cumbest et al., 1998, 2000). Based on the fault location and sense of movement, these faults can possibly be related to a series of other inverse faults in the region (i.e., Pen Branch, Crackerneck, Atta, Tinker Creek, Steel Creek, and Martin faults) associated with the formation of the Dunbarton Basin. Some of these faults were traced from within the crystalline basement upward into the UACP sediments inferring 

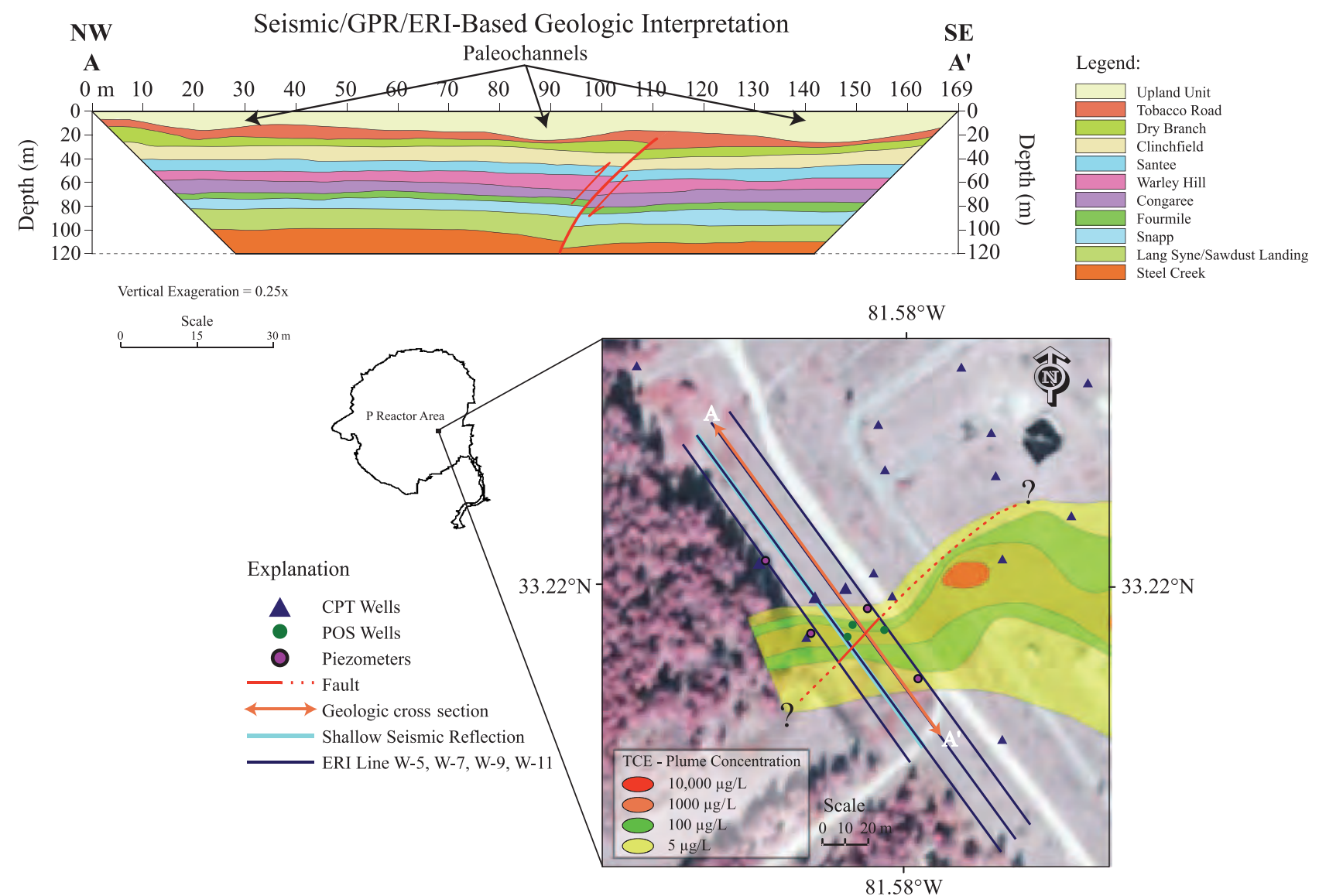

Figure 17. Interpreted geologic model from combined crosshole ground-penetrating radar, shallow seismic reflection, and electrical resistivity imaging (ERI) images. The location and extension of the interpreted inverse fault were traced in red line by correlating all these

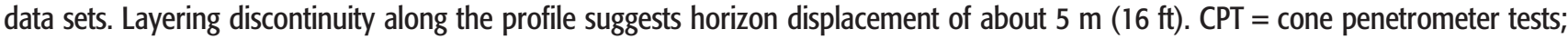
POS = position; TCE = trichloroethylene.

reactivation of the older Paleozoic-Mesozoic structures during the Cretaceous and Tertiary (Snipes et al., 1993).

The paleochannel complexes are shown in Figure 17, with a series of three potentially distinct channels. Also shown in Figure 17 is the surface projection of the fault plane (red line in the lower right inset). Based on the relative positions of the contaminant plume and the interpreted fault, one can notice a fairly sharp termination of the northern edge of the plume against the fault. However, the behavior of a contaminant plume depends mostly on the type of hydrogeological profile through which it is moving. Indeed, this could also explain why the plume narrows away from the source instead of an expected broadening. The length and width of the plume can be affected by the groundwater flow and velocity and the aquifer's hydraulic conductivity. Contaminant plumes are more elongated in groundwater with high velocity than in groundwater with low velocity (Liu and Liptak, 1999; Fetter, 2001). Moreover, a higher hydraulic conductivity can result in more rapid movement and a longer and narrower plume (Palmer, 1992). Geological structures such as faults and/or channels can affect the rate and direction of a migrating plume. Thus, the interpreted inverse fault can act as a barrier or a conduit to the TCE plume depending on the lithology against the walls of the fault. The interbeded clay lenses in the permeable sand facies (i.e., upper, middle, and lower sand) within the $P$ Reactor area can be splitting or retarding the sinking of the TCE plume and changing its shape course through time. Considering the results reported by Addison et al. (2009) and based on this interpretation, the migration of the plume appears likely to be constrained by (1) the presence of paleochannels in the subsurface (constraints on the plume migration direction), (2) the interpreted inverse fault (constraints on the structural evolution of the paleochannels), and (3) the local groundwater flow (constraint on the plume's longer and narrower shape away from the P Reactor and updip flow). 


\section{CONCLUSIONS}

Three geophysical techniques were used to image and characterize the lateral and shallow geology at the P Reactor area, SSR, South Carolina. During subsurface characterization efforts, combining a variety of geophysical methods was necessary to improve our understanding on the shallow stratigraphy and structural geology at different resolution scales where the TCE plume seems to migrate across the regional stratigraphic dip and narrow away to the west from the source. The results of this study suggest that (1) the CPT and natural gamma logs correlate well with the SSR, GPR, and ERI data sets; (2) the surface radar data show the presence of modern channels in the uppermost part of the sections; (3) the crosshole radar data provided useful information down to about 36-m (118-ft) depth between the POS-1 and POS-2 wells; (4) the SSR data imaged a subvertical discontinuity with vertical offsets of approximately $5 \mathrm{~m}$ (16 ft); (5) the conductivity tomogram between the POS- 1 and POS-3 wells shows a dipping near-vertical discontinuity at approximately 23-m (75-ft) depth; and (6) the ERI images show a low-resistivity discontinuity that correlates well with the discontinuity imaged on the SSR and crosshole GPR data. This discontinuity is consistent with the interpretation of a shallow inverse fault. The combination of all different geophysical techniques in this study suggests that the shallow $(\sim 23 \mathrm{~m}[75 \mathrm{ft}]$ from the ground surface) inverse fault within the unconsolidated sediments (upper Eocene and older) appears to contribute to the plume's geometry and shape.

A series of paleochannel structures within the upper $30+\mathrm{m}(98+\mathrm{ft})$ were interpreted on the SSR section, and they are also constrained by 3-D seismic data collected at the site (Addison et al., 2009). Interpretation and analysis of the SSR and surface GPR sections provide a detailed image of the overall internal structure and depositional patterns recorded within the sediments in the upper $16 \mathrm{~m}$ (52 ft) of a dynamic modern channel system. The hydraulic gradient calculated from potentiometric surface data between the piezometers indicates a convergence of groundwater flow near the area west of the POS wells.

How close to the surface the fault is is still uncertain; however, based on the SSR, crosshole GPR, and ERI data, it can be as shallow as approximately $23 \mathrm{~m}$ (75 ft) below ground surface. We believe that the geometry of the TCE plume is constrained by (1) the paleochannel system with respect to its migration direction, also suggested by Addison et al. (2009); (2) the presence of the inferred inverse fault that may contribute to the paleochannel growth and geometry; and (3) the local groundwater flow volume and direction updip stratigraphic bedding.

\section{REFERENCES CITED}

Aadland, R. K., J. A. Gellici, and P. A. Thayer, 1995, Hydrogeologic framework of west-central South Carolina: South Carolina Department of Natural Resources, Water Resource Division Report 5, $200 \mathrm{p}$.

Addison, A. D., M. G. Waddell, C. C. Knapp, D. T. Brantley, and J. M. Shafer, 2009, Developing a robust geologic conceptual model using pseudo 3-D P-wave seismic reflection data: Environmental Geosciences, v. 16, p. 1-16, doi:10.1306/eg.08110808003.

Annan, A. P., and J. L. Davis, 1992, Design and development of a digital ground penetrating radar system, in J. Pilon, ed., Ground penetrating radar: Geological Survey of Canada Paper 90-4, p. 49-55.

Aucott, W. R., 1996, Hydrology of the southeastern coastal plain aquifer system in South Carolina and parts of Georgia and North Carolina: U.S. Geological Survey Professional Paper 1410-E, 83 p.

Baker, G. S., D. W. Steeples, C. Schmeissner, M. Pavlovic, and R. Plumb, 2001, Near-surface imaging using coincident seismic and GPR data: Geophysical Research Letters, v. 28, p. 627630, doi:10.1029/2000GL008538.

Behrendt, J. C., R. M. Hamilton, H. D. Ackermam, V. J. Henry, and K. C. Bayer, 1983, Marine multi-channel seismic evidence for Cenozoic faulting and deep crustal structure near Charleston, South Carolina, in G. S. Gohn, ed., Studies related to the Charleston, South Carolina earthquake of 1886-Tectonics and seismicity: U.S. Geological Survey Professional Paper 1313, p. J1-J29.

Cederstrom, D. J., E. H. Boswell, and G. R. Tarver, 1979, Summary of appraisals of the Nation's ground-water resources-South Atlantic-Gulf Region: U.S. Geological Survey Professional Paper 813-O, 35 p.

Chapman, W. L., and M. P. Di Stefano, 1989, Savannah River plant seismic survey, 1987-88: Conoco Inc. Seismic Acquisition Section, Research Report 1809-005-006-1-89, 110 p.

Clement, W. P., W. Barrash, and M. D. Knoll, 2006, Reflectivity modeling of a ground-penetrating radar profile of a saturated fluvial formation: Geophysics, v. 71, p. K59-K66, doi:10 $.1190 / 1.2194528$.

Colquhoun, D. J., and M. G. Muthig, 1991, Stratigraphy and structure of the Paleocene and lower Eocene Black Mingo Group, South Carolina, in W. Horton Jr. and V. A. Zullo, eds., The geology of the Carolinas: Carolina Geological Society 50th Anniversary Volume: Knoxville, Tennessee, The University of Tennessee Press, p. 241-250.

Cumbest, R. J., D. E. Stephenson, D. E. Wyatt, and M. Maryak, 1998, Basement surface faulting for Savannah River site and vicinity: Westinghouse Savannah River Company, Technical Report, WSRC-TR-98-00346, 48 p.: http://www.osti.gov /bridge/servlets/purl/762016-yxu8iD/webviewable (accessed December 17, 1998).

Cumbest, R. J., D. E. Wyatt, D. E. Stephenson, and M. Maryak, 2000, Comparison of Cenozoic faulting at the Savannah River site to fault characteristics of the Atlantic Coast Fault Province: Implications for fault capability, Westinghouse Savannah River Company, Technical Report, WSRC-TR-2000-00310, 24 p.: 
http://sti.srs.gov/fulltext/tr2000310/tr2000310.html (accessed November 14, 2000).

Fallaw, W. C., and V. Price, 1992, Outline of stratigraphy at the Savannah River site, in W. C. Fallaw and V. Price, eds., Geological investigations of the central Savannah River area, South Carolina and Georgia: Carolina Geological Society, 1992 Annual Field Trip Guidebook, U.S. Department of Energy and SC Carolina Geological Survey, p. 17-40: http://sti.srs.gov/fulltext /ms2000606/ms2000606.pdf (accessed November 15, 2000).

Fallaw, W. C., and V. Price, 1995, Stratigraphy of the Savannah River site and vicinity: Southeastern Geology, v. 35, p. 21-58.

Fallaw, W. C., V. Price, and P. A. Thayer, 1990, Stratigraphy of the Savannah River site, South Carolina, in V. A. Zullo, W. Burleigh Harris, and V. Price, eds., Savannah River region: Transition between the Gulf and Atlantic coastal plains: Proceedings of the 2nd Bald Head Island Conference on Coastal Plains Geology, Wilmington, North Carolina, The University of North Carolina at Wilmington, p. 29-36.

Fetter, C. W., 2001, Applied hydrogeology: New Jersey, Upper Saddle River, 598 p.

Gross, R., A. G. Green, H. Horstmeyer, and J. H. Begg, 2004, Location and geometry of the Wellington fault (New Zealand) defined by detailed three-dimensional georadar data: Journal of Geophysical Research, v. 109, p. B05401, doi:10.1029/2003JB002615.

Hamilton, R. M., J. C. Behrendt, and H. D. Ackermam, 1983, Land multi-channel seismicreflection evidence for tectonic features near Charleston, South Carolina, in G. S. Gohn, ed., Studies related to the Charleston, South Carolina earthquake of 1886Tectonics and seismicity: U.S. Geological Survey Professional Paper 1313, p. I1-I18.

Higgins, B. B., G. S. Gohn, and L. M. Bybell, 1978, Subsurface geologic evidence for normal faults in the South Carolina coastal plain near Charleston: Geological Society of America Abstract with Programs, v. 10, 171 p.

Liu, D., and B. G. Liptak, 1999, Groundwater and surface water pollution: Chelsea, Michigan, Lewis Publishers, 160 p.

Lunne, T., P. K. Robertson, and J. J. M. Powell, 1997, Cone penetration testing in geotechnical practice: London, Blackie Academic and Professional, 312 p.

Marine, I. W., 1974, Geohydrology of buried Triassic basin at Savannah River plant, South Carolina: AAPG Bulletin, v. 58, p. 1825-1837.

Millings, M., K. Vangelas, and M. Harris, 2003, Source term determination for P-area reactor ground-water operable unit: Westinghouse Savannah River Company, Savannah River Site, Westinghouse Savannah River Company-TR-2003-00142, 1 p.

Mota, R., and F. Monteiro dos Santos, 2006, 2-D sections of porosity and water saturation percent from combined resistivity and seismic surveys for hydrogeologic studies: The Leading Edge, v. 25 , p. 735-737, doi:10.1190/1.2210058.

Neal, A., 2004, Ground-penetrating radar and its use in sedimentology: Principles, problems and progress: Earth-Science Reviews, v. 66, p. 261-330, doi:10.1016/j.earscirev.2004.01.004.

Nystrom Jr., P. G., R. H. Willoughby, and L. K. Price, 1991, Cretaceous and Tertiary stratigraphy of the upper coastal plain, South Carolina, in W. Horton Jr. and V. A. Zullo, eds., The geology of the Carolinas: Carolina Geological Society 50th Anniversary Volume: Knoxville, Tennessee, The University of Tennessee Press, p. 221-240.

Paillet, F. L., and K. J. Ellefsen, 2005, Downhole applications of geophysics, in D. K. Butler, ed., Near-surface geophysics: Part 1: Tulsa, Oklahoma, Society of Exploration Geophysicists, p. 439-471.

Palmer, C. M., 1992, Principles of contaminant hydrogeology: Chelsea, Michigan, Lewis Publishers, 256 p.

Peterson, J. E., 2001, Pre-inversion corrections and analysis of radar tomographic data: Journal of Environmental and Engineering Geophysics, v. 6, p. 1-18, doi:10.4133/JEEG6.1.1.

Pipan, M., E. Forte, G. Dal Moro, M. Sugan, and I. Finetti, 2003, Multifold ground-penetrating radar and resistivity to study the stratigraphy of shallow unconsolidated sediments: The Leading Edge, v. 22, p. 876-878, doi:10.1190/1.1614161.

Sangree, J. B., and J. M. Widmier, 1979, Interpretation of depositional facies from seismic data: Geophysics, v. 44, p. 131-160, doi:10.1190/1.1440957.

Schilt, S. F., L. D. Brown, J. E. Oliver, and S. Kaufman, 1983, Subsurface structure near Charleston, South Carolina-Results of Consortium for Continental Reflection Profiling (COCORP) reflection profiling in the Atlantic coastal plain, in G. S. Gohn, ed., Studies related to the Charleston, South Carolina earthquake of 1886-Tectonics and seismicity: U.S. Geological Survey Professional Paper 1313, p. H1-H19.

Shedlock, K. M., and S. T. Harding, 1988, Structure of the shallow crust near Charleston, South Carolina: Geological Society of America Abstract with Programs, v. 20, 313 p.

Siple, G. E., 1967, Geology and groundwater of the Savannah River plant and vicinity, South Carolina: U.S. Geological Survey, WaterSupply Paper 1841, 113 p.

Snipes, D. S., W. C. Fallaw, V. Price, and R. J. Cumbest, 1993, The Pen Branch fault: Documentation of Late Cretaceous-Tertiary faulting in the coastal plain of South Carolina: Southeast Geology, v. 33, p. 195-218.

Sohl, N. F., and J. P. Owens, 1991, Cretaceous stratigraphy of the Carolina coastal plain, in W. Horton Jr. and V. A. Zullo, eds., The geology of the Carolinas: Carolina Geological Society 50th Anniversary Volume: Knoxville, Tennessee, The University of Tennessee Press, p. 191-220.

Talwani, P., 1986, Current thoughts on the cause of the Charleston, South Carolina earthquakes: South Carolina Geology, v. 29, p. 19-38.

Ward, S. H., 1990, Resistivity and induced polarization methods, in S. H. Ward, ed., Geotechnical and environmental geophysics: Tulsa, Oklahoma, Society of Exploration Geophysicists, p. 147189

Wempe, W., and G. Mavko, 2006, A new method for constraining total porosity: The new total porosity-electrical resistivity upper bound: The Leading Edge, v. 25, p. 714-719, doi:10.1190 $/ 1.2210054$.

Wyatt, D. E., and T. J. Temples, 1996, Ground-penetrating radar detection of small-scale channels, joints and faults in the unconsolidated sediments of the Atlantic coastal plain: Environmental Geology, v. 27, p. 219-225, doi:10.1007/BF00770435.

Wyatt, D. E., M. G. Waddell, and G. B. Sexton, 1996, Geophysics and shallow faults in unconsolidated sediments: Ground Water, v. 34, p. 326-334, doi:10.1111/j.1745-6584.1996.tb01892.x.

Wyatt, D. E., R. K. Aadland, and F. H. Syms, 2000, Overview of the Savannah River site stratigraphy, hydrostratigraphy and structure, in D. E. Wyatt and M. K. Harris, eds., Savannah River site environmental remediation system in unconsolidated upper coastal-plain sediments, stratigraphic and structural considerations: Carolina Geological Society, 2000 Annual Field Trip Guidebook, WSRC-MS-2000-00606, p. A14-A48: http ://carolinageologicalsociety.org (accessed November 15, 2000).

Yilmaz, Ö., 1987, Seismic data processing: Investigations in geophysics, 2 d ed.: Tulsa, Oklahoma, Society Exploration Geophysics, $69 \mathrm{p}$.

Yilmaz, Ö., 2001, Seismic data analysis: Tulsa, Oklahoma, Society Exploration Geophysics, 2027 p.

Zoback, M. D., J. H. Healy, J. C. Roller, G. S. Gohn, and B. B. Higgins, 1978, Normal faulting and in situ stress in the South Carolina coastal plain near Charleston: Geology, v. 6, p. 147-152, doi:10 $.1130 / 0091-7613(1978) 6<147:$ NFAISS $>2.0 . C O ; 2$. 